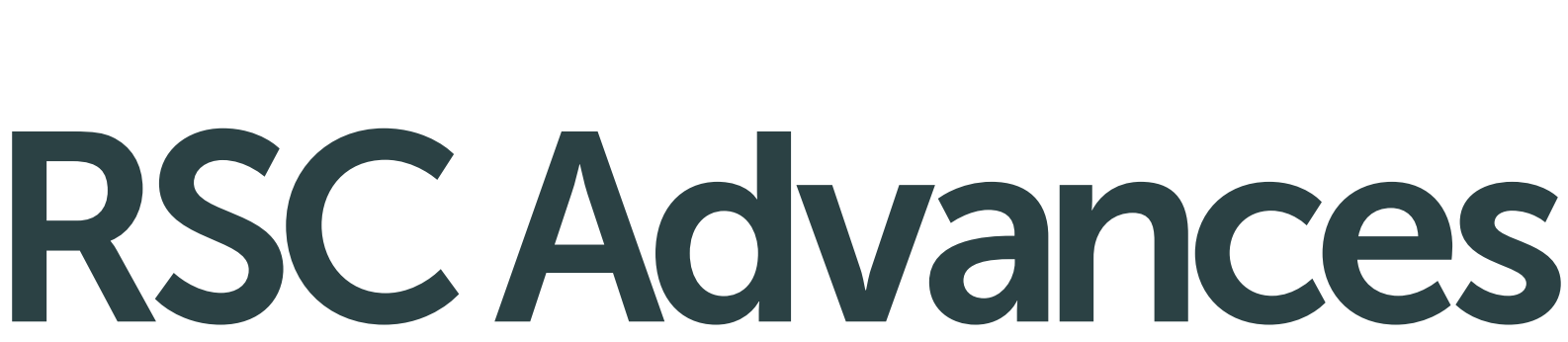

This article can be cited before page numbers have been issued, to do this please use: $\mathrm{S}$. Banerjee, $\mathrm{P}$ Brandao and A. Saha, RSC Adv., 2016, DOI: 10.1039/C6RA21217D.
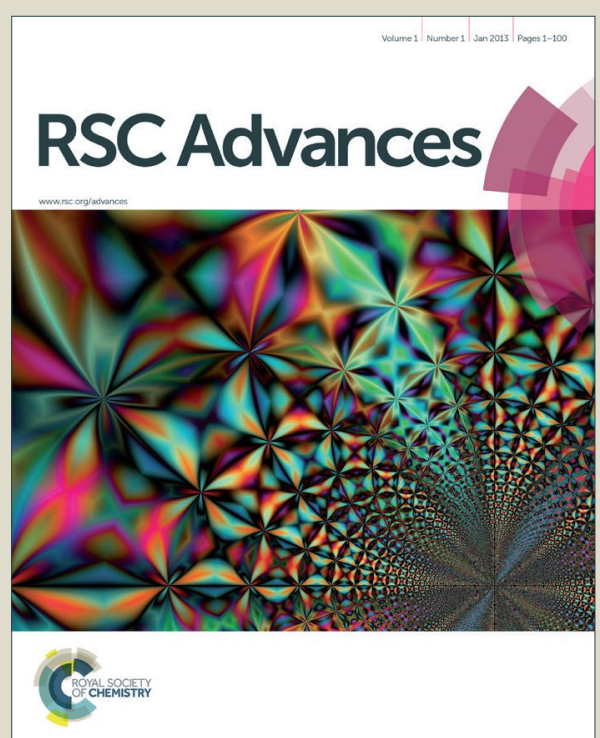

This is an Accepted Manuscript, which has been through the Royal Society of Chemistry peer review process and has been accepted for publication.

Accepted Manuscripts are published online shortly after acceptance, before technical editing, formatting and proof reading. Using this free service, authors can make their results available to the community, in citable form, before we publish the edited article. This Accepted Manuscript will be replaced by the edited, formatted and paginated article as soon as this is available.

You can find more information about Accepted Manuscripts in the Information for Authors.

Please note that technical editing may introduce minor changes to the text and/or graphics, which may alter content. The journal's standard Terms \& Conditions and the Ethical guidelines still apply. In no event shall the Royal Society of Chemistry be held responsible for any errors or omissions in this Accepted Manuscript or any consequences arising from the use of any information it contains. 


\section{A Robust Fluorescent Chemosensor for Aluminium Ion Detection \\ 2 Based on Schiff base Ligand with Azo Arm and Application in \\ 3 Molecular Logic Gate}

4 Saikat Banerjee, ${ }^{\mathbf{a}}$ Paula Brandão ${ }^{\mathbf{b}}$ and Amrita Saha ${ }^{\text {*a }}$

$5 \quad{ }^{a}$ Department of Chemistry, Jadavpur University, Kolkata- 700032, India.

E-mail: asaha@,chemistry.jdvu.ac.in; amritasahachemju@gmail.com; Tel.+91-33-24572941

$7{ }^{b}$ TEMA-NRD, Mechanical Engineering Department, University of Aveiro, 3810-193 Aveiro, 8 Portugal

Abstract

In this present work we reported synthesis and structural characterisations of a N2O2

12 donor Schiff base chemosensor with azo arm $\left(\mathbf{H}_{2} \mathbf{L}\right)$. Various spectroscopic tools like single

13 crystal X-ray, NMR, UV-vis, FTIR, ESI-Mass etc have been deployed to develop the present

14 work. In recent past years a number of azo derived chemosensors have been reported by different

15 research groups. This is first time we are reporting designing and properties of an azo derived

16 chemosensors $\left(\mathbf{H}_{2} \mathbf{L}\right)$ for detection of aluminium ion in semi aqueous medium. It has been found

17 that it selectively senses $\mathrm{Al}^{3+}$ ion in semi aqueous solution. Here, the sensing process is mainly

18 based on Chelation enhanced fluorescence process (CHEF). It has very high selectivity over

19 other metal ions and anions. A detailed literature survey has been carried out and compared with

20 this work. It has appreciably low detection limit i.e. $6.93 \mathrm{nM} .{ }^{1} \mathrm{HNMR}$ titration was done to

21 support the plausible complexation process. 1:1 stoichiometry binding between the chemosensor

22 and $\mathrm{Al}^{3+}$ ion has been confirmed from Job's plot. An inhibition molecular logic gate has been

23 constructed using Chemosensor $\left(\mathbf{H}_{2} \mathbf{L}\right)$, where $\mathrm{Al}^{3+}$ and EDTA act as inputs and Fluorescence 
24 emission as output. The structural and electronic parameters of the chemosensor $\left(\mathbf{H}_{2} \mathbf{L}\right)$ and

25 complex $[\mathrm{AL}(\mathrm{L})] \mathrm{NO}_{3}$ have been studied in details using theoretical tools like DFT and TDDFT.

\section{Introduction}

28 The design and construction of powerful and highly selective fluorescent chemosensors have

29 attracting considerable attention in biomimetic chemistry. ${ }^{1}$ Among various heavy metal ions

30 Aluminium is an essential element due to its abundance and use in every sphere of life as

31 utensils, electronic and electrical components of different gadgets, building equipment, different

32 packaging items, water treatments, food additives, pharmaceutical products, occupational dusts

33 etc. Aluminum is a known neurotoxin to organisms ${ }^{1}$ and is believed to cause Alzheimer's

34 disease, $^{2}$ osteomalacia ${ }^{3}$ and breast cancer. ${ }^{4}$ Toxicity due to the presence of excess aluminium in

35 human health may arise as it inhibits several essential elements of similar size and charge like

$36 \mathrm{Mg}^{2+}, \mathrm{Ca}^{2+}$ and $\mathrm{Fe}^{3+}$. It is also responsible for retarded growth of plants ${ }^{5}$ and oxidative damage of

37 the cell membrane. ${ }^{6}$ In spite of its many drawbacks, the enormous use of Al in daily life causes

38 accumulation of $\mathrm{Al}^{3+}$ and hence toxicity towards human health and the environment. WHO

39 recommended the average weekly human body dietary intake of $\mathrm{Al}^{3+}$ of around $7 \mathrm{mg} / \mathrm{kg}$ body

40 weight. ${ }^{7}$ Thus, it is utmost urgent to detect $\mathrm{Al}^{3+}$ ion in environment in trace level i.e. in ppb, ppm

41 or nano level. Unfortunately, the determination of $\mathrm{Al}^{3+}$ is complicated mainly due to its poor

42 coordination ability, strong tendency to hydration, and lack of suitable spectroscopic

43 characteristics. ${ }^{8}$ Some analytical methods are available for detection of $\mathrm{Al}^{3+}$ such as graphite

44 furnace atomic absorption spectrometry, inductively coupled plasma atomic emission

45 spectrometry, atomic absorption spectra, ${ }^{9}$ electrochemistry, ${ }^{10}$ mass spectrometry, ${ }^{11}$ and ${ }^{27} \mathrm{Al}$

46 NMR technology. ${ }^{12}$ Most of them are expensive and time consuming. Optical detection 
47 particularly fluorescence spectroscopic technique is advantageous over the other techniques

48 because of its operational simplicity, low cost, low detection limit, real-time detection,

49 selectivity, time saving and environmental friendly property. Therefore design and synthesis of

50 new chemosensor for the detection of $\mathrm{Al}^{3+}$ has received considerable attention. Recently various

51 research groups have reported different organic probes which can selectively detect $\mathrm{Al}^{3+} \cdot{ }^{13,14}$

52 Although example of such $\mathrm{Al}^{3+}$ detecting chemosensors are still less compared with other metal

53 ions detecting chemosensors like $\mathrm{Zn}^{2+}$ mainly due to less coordinating ability of $\mathrm{Al}^{3+}$ compared

54 to other metal ions. Therefore, more improvement in this field is still required. Current literature

55 survey (Table S1) reveals that preparation of most of the chemosensors for detection of $\mathrm{Al}^{3+}$

56 involves expensive stating materials, multiple reaction steps, use of different solvent mixtures

57 and maintenance of drastic reaction conditions i.e. very high or low temperature, presence of

58 catalyst etc. G. Das and et al. in a recent work ${ }^{14 \mathrm{n}}$ have reported an $\mathrm{Al}^{3+}$ sensing organic probe viz.

59 (E)-N'-((E)-3-(4-(dimethylamino)phenyl)allylidene)picolinohydrazide using starting materials

60 picolinohydrazide and 4-(dimethylamino)cinnamaldehyde. Preparation of picolinohydrazide

61 involves multiple steps. Preparation of another chemosensor viz. 2-((naphthalen-6-

62 yl)methylthio)ethanol involves inert atmosphere and finally the product has been purified

63 through column chromatography with $65 \%$ yield. ${ }^{14 \mathrm{e}} \mathrm{S}$. Goswami and coworkers have reported a

64 spirobenzopyran-quinoline (SBPQ) based sensor which selectively detects $\mathrm{Al}^{3+}$ along with $\mathrm{Fe}^{3+}$

65 and $\mathrm{Cr}^{3+}$. Preparation of this type of chemosensors also involves multiple steps. ${ }^{140}$ It is also

66 important to mention that 2-hydroxynapthaldehyde based organic probes are mostly used for

67 fluorescence sensing of $\mathrm{Al}^{3+} \cdot{ }^{14 \mathrm{p}}$

68 Different mechanistic pathway like intramolecular charge transfer (ICT), ${ }^{15}$ photo induced

69 electron transfer (PET), ${ }^{16}$ chelation-enhanced fluorescence (CHEF), ${ }^{17}$ metal-ligand charge 
70 transfer (MLCT), ${ }^{18}$ excimer/exciplex formation, imine isomerization, ${ }^{19}$ intermolecular hydrogen

71 bonding, ${ }^{20}$ excited-state intramolecular proton transfer, ${ }^{21}$ displacement approach, ${ }^{22}$ and

72 fluorescence resonance energy $\operatorname{transfer}^{23}$ are adopted to explain the action of different

73 fluorescence probe. Among different types of chemosensors, Schiff bases incorporated with

74 different functionalized moiety are widely used mainly due to their ease of synthesis and low

75 cost.

In this work an azo based salen-type of Schiff base ligand (E)-6,6'-((1E,1'E)-(propane-

77 1,3-diylbis(azanylylidene))bis(methanylylidene))bis(2-methoxy-4-((E)-phenyldiazenyl)phenol)

$78\left(\mathbf{H}_{2} \mathbf{L}\right)$ is structurally characterized and it exhibit high selectivity towards $\mathrm{Al}^{3+}\left(3.31 \times 10^{3} \mathrm{M}^{-1}\right)$

79 with low detection limit $(6.93 \mathrm{nM})$. Azo derivatives have prevalent use in different fields like

80 pharmaceuticals, optical data storage, non-linear optics, photo switching devices, textile industry

81 dye-sensitized solar cells and they also act as fluorescent chemosensors. ${ }^{24-30}$ Our work is

82 important and novel in this aspect because although various azo containing chemosensors are

83 reported in literature but to the best of our knowledge in this work we are first time reporting one

84 such sensor which can selectively detect $\mathrm{Al}^{3+}$. Our organic probe possesses some extra

85 advantages. We have prepared $\mathbf{H}_{\mathbf{2}} \mathbf{L}$ using easily available starting materials. The azoaldehyde

86 was prepared from well known easy diazotization process with very high yield. The azoaldehyde

87 upon reaction with a simple diamine produced $\mathbf{H}_{2} \mathbf{L}$ with $>90 \%$ yield. We have successfully

88 isolated both the azoaldehyde and Schiff base $\mathbf{H}_{\mathbf{2}} \mathbf{L}$ in highly crystalline form. The ligand is

89 characterized by different techniques including x-ray crystallography. The composition of the

$90 \mathrm{Al}^{3+}$-ligand complex (Complex 1) has been established by different spectroscopic data like IR,

91 Mass, Job's plot and ${ }^{1} \mathrm{H}$ NMR. The DFT computation of optimized geometry of $\mathbf{H}_{2} \mathbf{L}$ and the

92 complex $[\mathrm{Al}(\mathrm{L})]^{+}$has been used to support the electronic spectral properties. 


\section{Experimental}

\section{Materials and Physical measurements}

97 sources and used without further purification. Elemental analysis for $\mathrm{C}, \mathrm{H}$ and $\mathrm{N}$ was carried out

98 using a Perkin-Elmer 240C elemental analyzer. Infrared spectra (400-4000 $\left.\mathrm{cm}^{-1}\right)$ were recorded

99 from $\mathrm{KBr}$ pellets on a Nicolet Magna IR 750 series-II FTIR spectrophotometer. Absorption

100 spectra were measured using a UV-2450 spectrophotometer (Shimadzu) with a 1-cm-path-length

101 quartz cell. Measurements of NMR spectra were conducted using a Bruker 300 spectrometer in

102 DMSO- $\mathrm{d}_{6}$ and $\mathrm{CDCl}_{3}$ respectively. Emission was examined by LS 55 Perkin-Elmer

103 spectrofluorimeter at room temperature $(298 \mathrm{~K})$ in HEPES buffer at $\mathrm{pH}=7.4$ solution under

104 degassed condition. Fluorescence lifetimes were measured using a time-resolved 105 spectrofluorimeter from IBH, UK.

\section{Synthesis of (E)-5-(2-phenyldiazenyl)-2-hydroxy-3-methoxybenzaldehyde}

$4 \mathrm{~mL}$ conc. $\mathrm{HCl}$ was added to $15 \mathrm{~mL}$ water and kept in an ice bath keeping the

108 temperature $0^{0} \mathrm{C}$. To it, aniline $(4.0 \mathrm{mmol}, 0.372 \mathrm{~g})$ was added. To this mixture an aqueous

109 solution of sodium nitrite $(6.0 \mathrm{mmol}, 0.414 \mathrm{~g})$ was drop wise added over a time of $30 \mathrm{mins}$. The

110 mixture was stirred for $1 \mathrm{~h}$ at $0^{0} \mathrm{C}$. Then the resultant solution was added to the alkaline $o$ -

111 Vanillin (4.8 mmol, $0.732 \mathrm{~g}$ ) which is kept in another ice bath. The mixture was further stirred

112 for $1 \mathrm{~h}$ at $0^{0} \mathrm{C}$. The solution was neutralised using dilute $\mathrm{HCl}$ and $\mathrm{p}^{\mathrm{H}}$ was maintained around 7.0.

113 The mixture was extracted with chloroform and evaporated to result red coloured crystals of the 114 aldehyde. 
115 Yield: 0.953 g (94\%). Anal. Calc. for $\mathrm{C}_{14} \mathrm{H}_{12} \mathrm{~N}_{2} \mathrm{O}_{3}$ : C 64.65\%; H 5.79\%; N 16.34\%. Found: C

$116 \quad 64.36 \%$; H 5.31\%; N 16.17\%.IR ( $\left.\mathrm{cm}^{-1}, \mathrm{KBr}\right): \mathrm{v}(\mathrm{N}=\mathrm{N}) 1459 \mathrm{~s} ; \mathrm{v}(\mathrm{C}-\mathrm{H}) 762$ s. ESI-MS (positive) in

$117 \mathrm{MeOH}$ : The base peak was detected at $m / z=279.00$, corresponding to $[\mathrm{M}+23]^{+}$.

$118{ }^{1} \mathrm{H}$ NMR $\left(\mathrm{CDCl}_{3}, 300 \mathrm{MHz}\right) \delta \mathrm{ppm}: 4.01\left(-\mathrm{OCH}_{3}\right)(\mathrm{s}, 3 \mathrm{H}), 7.25-7.35(\mathrm{Ar}-\mathrm{H})(\mathrm{m}, 2 \mathrm{H}), 7.74-7.86$

$119(\mathrm{Ar}-\mathrm{H})(\mathrm{m}, 5 \mathrm{H}), 10.02(-\mathrm{CH}=\mathrm{O})(\mathrm{s}, 1 \mathrm{H}), 11.05(-\mathrm{OH})(\mathrm{bs}, 1 \mathrm{H})$.

\section{Synthesis of Schiff base ligand $\left(\mathbf{H}_{2} \mathbf{L}\right)$}

121

A mixture of (E)-5-(2-phenyldiazenyl)-2-hydroxy-3-methoxybenzaldehyde (2.0 mmol)

122 and 1,3-diaminopropane $(1.0 \mathrm{mmol}, 0.074 \mathrm{~g})$ was heated to reflux for $4 \mathrm{~h}$ in methanol-

123 chloroform solvent mixture $(1: 1, \mathrm{v} / \mathrm{v})$. Upon slow evaporation of the solvent mixture deep red

124 colored crystals were obtained.

125 Yield: $0.5282 \mathrm{~g}$ (96\%). Anal. Calc. for $\mathrm{C}_{29} \mathrm{H}_{26} \mathrm{~N}_{6} \mathrm{O}_{2}$ : C 67.62\%; H 5.49\%; N 15.26\%. Found: C $126 \quad 66.86 \%$; H 5.31\%; N 14.97\%.IR (cm $\left.{ }^{-1}, \mathrm{KBr}\right): v(\mathrm{C}=\mathrm{N}) 1648 \mathrm{~s} ; \mathrm{v}(\mathrm{N}=\mathrm{N}) 1455 \mathrm{~s} ; \mathrm{v}(\mathrm{C}-\mathrm{H}) 764$ s. ESI-

127 MS (positive) in $\mathrm{MeOH}$ : The base peak was detected at $m / z=551.21$, corresponding to $[\mathrm{M}+1]^{+}$.

$128 \mathrm{UV}-\mathrm{Vis}, \lambda_{\max }(\mathrm{nm}),\left(\varepsilon\left(\mathrm{dm}^{3} \mathrm{~mol}^{-1} \mathrm{~cm}^{-1}\right)\right)$ in Acetonitrile: $290(4533)$ and $388(5736)$.

$129{ }^{1} \mathrm{H}$ NMR $\left(\mathrm{CDCl}_{3}, 300 \mathrm{MHz}\right) \delta \mathrm{ppm}: 2.25\left(-\mathrm{CH}_{2}\right)(\mathrm{m}, 1 \mathrm{H}), 3.82-3.84\left(-\mathrm{CH}_{2}\right)(\mathrm{bs}, 2 \mathrm{H}), 4.01(-$ $\left.130 \mathrm{OCH}_{3}\right)(\mathrm{s}, 3 \mathrm{H}), 7.42-7.90(\mathrm{Ar}-\mathrm{H})(\mathrm{m}, 7 \mathrm{H}), 8.43(-\mathrm{CH}=\mathrm{N})(\mathrm{s}, 1 \mathrm{H})$.

$131{ }^{1} \mathrm{H}$ NMR $\left(\mathrm{DMSO}_{6}, 300 \mathrm{MHz}\right) \delta \mathrm{ppm}: 2.08\left(-\mathrm{CH}_{2}\right)(\mathrm{m}, 2 \mathrm{H}), 3.74-3.82\left(-\mathrm{CH}_{2},-\mathrm{OCH}_{3}\right)(\mathrm{bs}$, $13210 \mathrm{H}), 7.30-7.48(\mathrm{Ar}-\mathrm{H})(\mathrm{m}, 8 \mathrm{H}), 7.66-7.74(\mathrm{Ar}-\mathrm{H})(\mathrm{m}, 6 \mathrm{H}), 8.66(-\mathrm{CH}=\mathrm{N})(\mathrm{s}, 2 \mathrm{H})$.

$133{ }^{13} \mathrm{C}$ NMR (DMSO-d $\left.6,75 \mathrm{MHz}\right) \delta$ ppm: $31.46\left(-\mathrm{CH}_{2}\right), 56.34\left(-\mathrm{CH}_{2}\right), 118.22,122.58,126.93$, $134127.41,129.08$ and $130.47(\mathrm{Ar}-\mathrm{C}), 165.38(-\mathrm{CH}=\mathrm{N})$. 
136

138

139 of triethylamine $(2.0 \mathrm{mmol}, \sim 0.4 \mathrm{~mL})$ and the resultant reaction mixture was stirred for $4 \mathrm{~h}$ under

140 nitrogen atmosphere. Then the resultant mixture was dried to powdered form and further

141 characterizations were carried out.

142 Yield: $0.6246 \mathrm{~g}(98 \%)$. Anal. Calc. for $\mathrm{AlC}_{29} \mathrm{H}_{24} \mathrm{~N}_{7} \mathrm{O}_{5}$ : C 67.62\%; H 5.49\%; N 15.26\%. Found:

143 C 66.86\%; H 5.31\%; N 14.97\%.IR $\left(\mathrm{cm}^{-1}, \mathrm{KBr}\right): v(\mathrm{C}=\mathrm{N}) 1646 \mathrm{~s} ; \mathrm{v}(\mathrm{N}=\mathrm{N}) 1545 \mathrm{~s} ; \mathrm{v}(\mathrm{C}-\mathrm{H}) 770 \mathrm{~s}$.

144 ESI-MS (positive) in $\mathrm{MeOH}$ : The base peak was detected at $m / z=575.25$, corresponding to

$145[\mathrm{Al}(\mathrm{L})]^{+} . \mathrm{UV}-\mathrm{Vis}, \lambda_{\max }(\mathrm{nm}),\left(\varepsilon\left(\mathrm{dm}^{3} \mathrm{~mol}^{-1} \mathrm{~cm}^{-1}\right)\right)$ in Acetonitrile: $286(5083)$ and 375 (5949).

$146{ }^{1} \mathrm{H}$ NMR $\left(\mathrm{DMSO}_{6}, 300 \mathrm{MHz}\right) \delta \mathrm{ppm}: 2.16\left(-\mathrm{CH}_{2}\right)(\mathrm{bs}, 2 \mathrm{H}), 3.89-3.95\left(-\mathrm{CH}_{2},-\mathrm{OCH}_{3}\right)(\mathrm{bs}$, $14710 \mathrm{H})$, 7.54-7.81 (Ar-H) $(\mathrm{m}, 14 \mathrm{H}), 9.24(-\mathrm{CH}=\mathrm{N})(\mathrm{s}, 2 \mathrm{H})$.

Single crystal X-ray data of azoaldehyde and Schiff base ligand $\left(\mathbf{H}_{\mathbf{2}} \mathbf{L}\right)$ were collected on

150 a Bruker SMART APEX-II CCD diffractometer using graphite monochromated Mo Ka

151 radiation $(\lambda=0.71073 \AA)$ at room temperature. Data processing, structure solution, and

152 refinement were performed using Bruker Apex-II suite program. All available reflections $2 \theta_{\max }$

153 were harvested and corrected for Lorentz and polarization factors with Bruker SAINT plus. $^{31}$

154 Reflections were then corrected for absorption, inter-frame scaling, and other systematic errors

155 with SADABS. ${ }^{32}$ The structures were solved by the direct methods and refined by means of full

156 matrix least-square technique based on $\mathrm{F}^{2}$ with SHELX-1997 and SHELX-2013 software

157 package. ${ }^{33}$ All the non-hydrogen atoms were refined with anisotropic thermal parameters. C-H 
158 hydrogen atoms were inserted at geometrical positions with $U_{\text {iso }}=1 / 2 U_{\text {eq }}$ to those they are

159 attached. Crystal data and details of data collection and refinement are summarized in Table 1.

160 Computational method

161 All computations were performed using the GAUSSIAN09 (G09) ${ }^{33}$ software package.

162 Coordinates obtained from single crystal X-ray data were used for optimization of structure of

163 Ligand $\left(\mathbf{H}_{2} \mathbf{L}\right)$. For optimization we used the density functional theory method at the B3LYP

164 level $^{35,36}$ and the standard $6-31+\mathrm{G}(\mathrm{d})$ basis set for $\mathrm{C}, \mathrm{H}, \mathrm{N}$ and $\mathrm{O}$ atoms ${ }^{36,38}$ and the lanL2DZ

165 effective potential (ECP) set of Hay and Wadt ${ }^{39-41}$ for aluminum atom have been chosen for 166 optimization .

167 TDDFT calculation was performed with the optimized geometry to ensure only positive 168 eigen values. Time-dependent density functional theory (TDDFT) ${ }^{42-44}$ was performed using 169 conductor-like polarizable continuum model $(\mathrm{CPCM})^{44-47}$ and the same B3LYP level and basis 170 sets in aqueous solvent system. GAUSSSUM ${ }^{48}$ was used to calculate the fractional contributions 171 of various groups to each molecular orbital.

\section{Results and discussion}

173 Synthesis and Characterization

174 The azoaldehyde5-(2-phenyldiazenyl)-2-hydroxy-3-methoxybenzaldehyde is synthesized

175 by first diazotization of primary aromatic amine (aniline) followed by coupling with an aromatic 176 alcohol (o-vanillin). Azoaldehyde reacted with 1,3-diamino propane in 2:1 molar ratio at ambient 177 temperature in methanol to generate the Chemosensor $\mathbf{H}_{2} \mathbf{L}$ (Scheme 1). The yield of both the 178 aldehyde and $\mathbf{H}_{2} \mathbf{L}$ is $>90 \%$. Both of them are crystallized from slow evaporation of methanol179 chloroform (3:5) mixture. They are well characterized by ${ }^{1} \mathrm{H}$ NMR, ${ }^{13} \mathrm{C}$ NMR, mass and IR 
180 spectroscopy. In IR spectrum, azo $(\mathrm{N}=\mathrm{N})$ band of both azoaldehyde and $\mathbf{H}_{2} \mathbf{L}$ appear at $1459 \mathrm{~cm}^{-1}$ 181 and $1455 \mathrm{~cm}^{-1}$ respectively (Fig. S1). Other important stretching vibrations of $\mathbf{H}_{2} \mathbf{L}$ are 1648 (s, $182 v(\mathrm{C}=\mathrm{N})) ; 3100 \mathrm{~cm}^{-1}(\mathrm{v}(-\mathrm{OH})) ; 764 \mathrm{~cm}^{-1}(\mathrm{v}(\mathrm{C}-\mathrm{H}))$ respectively. Similar characteristic stretching 183 frequencies of $[\mathrm{Al}(\mathrm{L})] \mathrm{NO}_{3}$ are obtained at $1646(\mathrm{~s}, v(\mathrm{C}=\mathrm{N})) ; 1530 \mathrm{~cm}^{-1}(\mathrm{v}(\mathrm{N}=\mathrm{N})) ; 770 \mathrm{~cm}^{-1}(v(\mathrm{C}-$ $184 \mathrm{H}$ )), respectively (Fig. S2). In complex 1, nitrate ion is present as a counter anion. The 185 characteristic stretching frequencies are obtained at $765 \mathrm{~cm}^{-1}$ (planar rock), $815 \mathrm{~cm}^{-1}$ (NO, 186 deformation) and $1375 \mathrm{~cm}^{-1}$ (NO, asymmetric stretch), respectively, which are comparable with 187 that of previously reported literature values. ${ }^{49}$ In ${ }^{1} \mathrm{H}$ NMR spectrum of azoaldehyde $\left(\mathrm{CDCl}_{3}\right.$ 188 solvent), aldehyde proton $(-\mathrm{CH}=\mathrm{O})$ appeared at $10.02 \mathrm{ppm}$ whereas $-\mathrm{OCH}_{3}$ and phenolic $-\mathrm{OH}$ 189 protons appeared at $4.01 \mathrm{ppm}$ and $11.05 \mathrm{ppm}$ respectively. Azoaldehyde contains two aromatic 190 rings. Aromatic protons came as multiplate at two different regions i.e. from 7.25 to $7.35 \mathrm{ppm}$ 191 and from 7.74 to 7.86 ppm respectively. In case of the $\mathbf{H}_{2} \mathbf{L}\left(\mathrm{CDCl}_{3}\right.$ solvent), aromatic protons 192 appear around 7.74-7.30 ppm whereas azomethine proton, $-\mathrm{OCH}_{3}$ protons and aliphatic protons 193 appeared at 8.43, 4.01, 3.95and 2.25 ppm respectively. Here, Phenolic -OH proton is so labile 194 that it becomes very difficult to arrest in both $\mathrm{CDCl}_{3}$ and $\mathrm{DMSO}-\mathrm{d}_{6}$ solvent system. In ${ }^{13} \mathrm{C}$ 195 spectra of $\mathbf{H}_{2} \mathbf{L}$ (DMSO-d ${ }_{6}$ solvent), aliphatic carbon signals appeared at 31.46 ppm and 56.34 196 ppm respectively, whereas aromatic carbons appeared in the region of $118 \mathrm{ppm}$ to $130 \mathrm{ppm}$. The 197 signal at $165 \mathrm{ppm}$ is the characteristic signal for imine carbon $(>C=N)$ (Fig. S3-S6). Mass 198 spectral analysis of starting azoaldehyde and $\mathbf{H}_{2} \mathbf{L}$ exhibit $\mathrm{m} / \mathrm{z}$ peaks at 279.00 and 551.21, 199 respectively (Fig.S7-S9). Mass spectrum of $\mathbf{H}_{2} \mathbf{L}$ in the presence of $\mathrm{Al}^{3+}$ shows peak $m / z$ at 575.25 200 which is corresponding to $\left[(\mathrm{Al}(\mathrm{L})]^{+}\right.$(Fig. S10).

201 The structure of both azoaldehyde and $\mathbf{H}_{\mathbf{2}} \mathbf{L}$ has been established by single crystal X-ray 202 diffraction measurement. Crystals of both the organic compound are obtained from slow 
203 evaporation of $\mathrm{CH}_{2} \mathrm{Cl}_{2}-\mathrm{CH}_{3} \mathrm{OH}$ solvent mixture. The ORTEP plot of azoaldehyde and $\mathbf{H}_{2} \mathbf{L}$ are

204 shown in Fig. 1 and Fig. 2 respectively and the selected bond parameters are listed in Table 2.

205 The azoaldehyde crystallizes with a monoclinic space group Cc. It has almost planer structure

206 where the azo nitrogen atoms and the aromatic ring containing $-\mathrm{CHO},-\mathrm{OCH}_{3},-\mathrm{OH}$ groups

207 belong in the same plane. The remaining aromatic ring deviates from the plane to a small extent

$208\left(10.71^{\circ}\right)$. The $\mathrm{N}=\mathrm{N}$ and $\mathrm{C}=\mathrm{O}(-\mathrm{CHO})$ bond distances are $1.252 \AA$ and $1.224 \AA$ respectively which

209 are similar with other reported values. ${ }^{50}$ Aromatic C-C bond distances observed around 1.368 -

$2101.404 \AA$. In solid state it form 2D network through intermolecular hydrogen bonding between the

211 phenoxy o-atom and aromatic hydrogen atom and edge to edge $\pi-\pi$ stacking interaction between

212 two phenyl rings. The distances are $2.704 \AA$ and $3.70 \AA$ respectively (Fig. S11).

213 The Schiff base ligand $\left(\mathbf{H}_{2} \mathbf{L}\right)$ crystallizes with a triclinic space group $P \overline{1}$. The azo $-\mathrm{N}=\mathrm{N}-$

214 bond distances are $1.217 \AA$ and $1.268 \AA$ respectively. The average $\mathrm{C}=\mathrm{N}$ - bond distance is 1.287

$215 \AA$. The C-C bond distances of the phenyl rings found around 1.342-1.472 $\AA$, whereas aliphatic

216 C-C bond distances appear around 1.511-1.531 $\AA$. The propylenic part of the Schiff base, N3-

217 C15-C16-C17-N4, is to some extent puckered due to the $\mathrm{sp}^{3}$ hybridization of the saturated

218 portion of the ligand. The bond angle $\left(\mathrm{C} 15-\mathrm{C} 16-\mathrm{C} 17,114.35(6)^{\circ}\right.$ deviates appreciably from its

219 ideal value. $\mathrm{OH}$ group of the both of phenyl ring are placed $180^{\circ}$ apart from each other to

220 minimize the dipole-dipole interaction. In the Schiff base ligand each azo nitrogen atoms, imine

221 atoms and the aromatic ring containing $-\mathrm{CHO},-\mathrm{OCH}_{3},-\mathrm{OH}$ groups belong in the same plane.

222 The remaining aromatic ring deviates from the plane significantly by an angle of $83.03^{\circ}$.The

223 molecule dimerizes in solid state through intermolecular $\mathrm{H}$-bonding between the two $-\mathrm{OH}$

224 groups as well as between the $-\mathrm{OH}$ group and imine nitrogen atom. $-\mathrm{O}-\mathrm{H}$... $\mathrm{O}$ bond distance is

$2253.879 \AA$ whereas $-\mathrm{O}-\mathrm{H} \ldots \mathrm{N}$ (imine) bond distance is $2.357 \AA$ (Fig. S12). 
227 bond distances are marginally elongated by $0.0023-0.0435 \AA$ and bond angles varies within the

228 range of $0.05-1.39^{\circ}$ (Table 2) compare with the X-ray crystallographic data. Therefore, the

229 optimized results are helpful to explain the electronic structure and electronic properties of the

230 ligand $\mathbf{H}_{\mathbf{2}} \mathbf{L}$.

\section{Absorption study}

232 The UV-Vis spectrum of the Chemosensor $\mathbf{H}_{2} \mathbf{L}$ was recorded at $25^{\circ} \mathrm{C}$ in aqueous buffer233 acetonitrile solution (1:100 v/v, HEPES buffer at $\mathrm{pH} 7.4)$ which exhibited well-defined bands at

234290 and $388 \mathrm{~nm}$ respectively. In order to study the binding property of $\mathbf{H}_{2} \mathbf{L}$ toward $\mathrm{Al}^{3+}$ ion, $235 \mathrm{UV}-\mathrm{Vis}$ spectra of $\mathbf{H}_{\mathbf{2}} \mathbf{L}(10 \mu \mathrm{M})$ in the presence of various concentrations of $\mathrm{Al}^{3+}(0-10 \mu \mathrm{M})$

236 were recorded at room temperature, as shown in Fig. 3. It has been observed that old peaks 237 disappear and two new absorption bands emerge at 286 and $375 \mathrm{~nm}$ respectively, and its 238 absorbance gradually increases with the gradual addition of $\mathrm{Al}^{3+}$ and it gets saturated upon 239 addition of 1.0 equivalents of $\mathrm{Al}^{3+}$ keeping the concentration of $\mathbf{H}_{2} \mathbf{L}$ fixed at $10 \mu \mathrm{M}$. These 240 observations indicate the coordination of $\mathbf{H}_{2} \mathbf{L}$ with one eq. of $\mathrm{Al}^{3+}$ (Fig. 3).

\section{$241 \quad \mathbf{A l}^{3+}$ ion sensing by fluorescence studies}

242 The fluorescence property of $\mathbf{H}_{2} \mathbf{L}$ was also investigated in HEPES buffer solution at $\mathrm{pH} 7.4$ at

243 room temperature. The ligand, $\mathbf{H}_{2} \mathbf{L}$, emits weakly at $510 \mathrm{~nm}$ when excited at $388 \mathrm{~nm}$ and the

244 fluorescence quantum yield is $\left(\Phi=\mathbf{H}_{2} \mathbf{L}\right)$ 0.00939. Upon excitation at $290 \mathrm{~nm}$ we observed 245 similar emission at $510 \mathrm{~nm}$. Low fluorescence intensity of free $\mathbf{H}_{2} \mathbf{L}$ probably due to photo 246 induced electron transfer process (PET) caused by electron delocalization from the two 247 phenoxido oxygen atoms to the $\pi$-conjugated system of two aromatic rings, $>\mathrm{C}=\mathrm{N}-$ group and 248 azo $(-\mathrm{N}=\mathrm{N}-)$ group. Here presence of extended delocalization through azo group $(-\mathrm{N}=\mathrm{N}-)$ 
249 initiates appearance of fluorescence pick at $510 \mathrm{~nm}$. After gradual addition of $\mathrm{Al}^{3+}$ ion with

250 various concentrations $(0-10 \mu \mathrm{M})$, a significant changes in emission spectra have been noticed.

251 In presence of metal ion the emission band of $\mathbf{H}_{\mathbf{2}} \mathbf{L}$ is blue shifted to $478 \mathrm{~nm}$. This result also

252 confirms a high sensitivity of the receptor towards $\mathrm{Al}^{3+}$. A plot of fluorescence intensities at 478

$253 \mathrm{~nm}\left(\mathrm{I}_{478}\right)$ vs concentration of aluminum has been given in Fig. 4. : inset. It shows that sensing

254 character of $\mathbf{H}_{2} \mathbf{L}\left(\mathrm{I}_{478}\right)$ increases with the increasing concentration of $\mathrm{Al}^{3+}$ and a clear bend of the

255 curve was observed at 1.0 equivalent of added $\mathrm{Al}^{3+}$ which prove $1: 1$ stoichiometry of the

$256[\mathrm{Al}(\mathrm{L})]^{+}$. Such type of sigmoid curve reflects nature of interaction between the organic probe and

$257 \mathrm{Al}^{3+}$ ion. Upon addition of $1-3 \mu \mathrm{M}$ of $\mathrm{Al}^{3+}$ to $10 \mu \mathrm{M}$ solution of chemosensor, very small change

258 of fluorescence intensity of the probe at wavelength $478 \mathrm{~nm}$ has been observed. Upon gradual

259 addition of $\mathrm{Al}^{3+}$ from 4-9 $\mu \mathrm{M}$ fluorescence intensity increases from 300-1400 a.u. which

260 indicates strong interaction between Schiff base ligand and $\mathrm{Al}^{3+}$. Maximum increase of

261 fluorescence intensity has been observed upto $10 \mu \mathrm{M}$ addition of $\mathrm{Al}^{3+}$. This clearly indicates a

$2621: 1$ binding between $\mathbf{H}_{2} \mathbf{L}$ and $\mathrm{Al}^{3+}$. The curve became a plateau with further addition of $\mathrm{Al}^{3+}$,

263 when further increment in fluorescence intensity has not been observed.

264 Enhancement in fluorescence intensity of $\mathbf{H}_{2} \mathbf{L}$ in presence of $\mathrm{Al}^{3+}$ probably due to 265 elimination of photoinduced electron transfer (PET) in free $\mathbf{H}_{2} \mathbf{L}$ followed by chelation 266 enhancement effect (CHEF) through the co-ordination of azomethine-N and phenolic-O to metal

267 ion (Scheme 2). Hence, upon complexation a large CHEF effect is observed because of the rigid

268 framework and thereby obstructs the PET process. Thus, upon coordination with $\mathrm{Al}^{3+}$ ion, the

269 PET process within the ligand system would become weak by reduction of either the electron-

270 accepting ability of the $\pi$-conjugated system of two aromatic rings, $>\mathrm{C}=\mathrm{N}-$ and azo $(-\mathrm{N}=\mathrm{N}-)$

271 groups or the electron-donating ability of the phenoxido oxygen atoms. 
Fluorescence intensity of $\mathbf{H}_{2} \mathbf{L}$ has been examined with various cations $\left(\mathrm{Cd}^{2+}, \mathrm{Co}^{2+}, \mathrm{Cr}^{3+}\right.$,

$273 \mathrm{Cu}^{2+}, \mathrm{Fe}^{3+}, \mathrm{Hg}^{2+}, \mathrm{K}^{+}, \mathrm{Mn}^{2+}, \mathrm{Na}^{+}, \mathrm{Ni}^{2+}, \mathrm{Sn}^{2+}, \mathrm{Zn}^{2+}, \mathrm{Ag}^{+}, \mathrm{Fe}^{2+}$ and $\mathrm{Ca}^{2+}$ ) using their nitrate salt. (Fig.

274 S13). Fig. S13 shows that only $\mathrm{Al}^{3+}$ can induce significant enhancement of fluorescence

275 intensity. Interestingly, upon addition of different metal ions the intensity of the fluorescence

276 either remains unchanged or weakened. In presence of $\mathrm{Co}^{2+}, \mathrm{Cr}^{3+}, \mathrm{Cu}^{2+}, \mathrm{K}^{+}, \mathrm{Mn}^{2+}, \mathrm{Na}^{+}, \mathrm{Ni}^{2+}, \mathrm{Fe}^{2+}$

277 and $\mathrm{Ca}^{2+}$ metal ions emission intensity remain almost unchanged and in presence of $\mathrm{Fe}^{3+} \mathrm{Cd}^{2+}$,

$278 \mathrm{Sn}^{2+}, \mathrm{Ag}^{+}, \mathrm{Hg}^{2+}$, and $\mathrm{Zn}^{2+}$ metal ions emission intensity slightly increased (Fig. S13). A

279 competition assay of $\mathbf{H}_{2} \mathbf{L}$ in the presence of $\mathrm{Al}^{3+}$ and other metal ions have also been studied and

280 presented in Fig. 5, which prove that fluorescence enhancement due to $\mathrm{Al}^{3+}$ nullify the possible

281 interference of other metal ions. Upon addition of different anions viz. $\mathrm{S}_{2} \mathrm{O}_{3}{ }^{2-}, \mathrm{S}^{2-}, \mathrm{SO}_{3}{ }^{2-}, \mathrm{SO}_{4}{ }^{2-}$,

$282 \mathrm{SCN}^{-}, \mathrm{N}_{3}^{-}, \mathrm{AsO}_{4}{ }^{3-}, \mathrm{PO}_{4}{ }^{3-}, \mathrm{ClO}_{4}{ }^{-}, \mathrm{AcO}^{-}, \mathrm{Cl}^{-}, \mathrm{NO}_{2}{ }^{-}, \mathrm{NO}_{3}{ }^{-}$and $\mathrm{SCN}^{-}$in HEPES buffer at $\mathrm{pH} 7.4$ (Fig.

283 6) chemosensor $\mathbf{H}_{2} \mathbf{L}$ showed no significant fluorescence enhancement. Thus, the probe is an

284 excellent example of fluorescence chemosensor towards $\mathrm{Al}^{3+}$ in the presence of different metal 285 ions.

286 To find out the binding ability of our chemosensor $\mathbf{H}_{2} \mathbf{L}$ with $\mathrm{Al}^{3+}$ ions, binding constant 287 was calculated using Benesi-Hildebrand equation (Equation 1) involving fluorescence titration 288 curve.

$289 \frac{F_{\max }-F_{0}}{F_{x}-F_{0}}=1+\left(\frac{1}{K[C]^{n}}\right)$

290 Where, $F_{\max }, F_{0}$ and $F_{x}$ are fluorescence intensities of $\mathbf{H}_{2} \mathbf{L}$ in the presence of $\mathrm{Al}^{3+}$ at 291 saturation, free $\mathbf{H}_{2} \mathbf{L}$ and any intermediate $\mathrm{Al}^{3+}$ concentration at $\lambda_{\max }=478 \mathrm{~nm}$. $\mathrm{K}$ is the 292 dissociation constant of the complex. Concentration of $\mathrm{Al}^{3+}$ ions is represented by $\mathrm{C}$ and slop $\mathrm{n}$ is 293 measured with Hill plot. Then Binding constant $(\mathrm{Ka})$ of the complex has been determined using 
294 the relation, $\mathrm{Ka}=1 / \mathrm{K}_{\mathrm{d}}$. A plot of $\frac{F_{\max }-F_{0}}{F_{x}-F_{0}}$ vs $\left(\frac{1}{[M]^{1}}\right)$ provides the apparent binding constant value 295 as $3.31 \times 10^{3} \mathrm{M}^{-1}$ (Fig. S14) $(\mathrm{n}=1.0) .{ }^{14 \mathrm{e}}$ The Job's plot suggests that the ligand $\mathbf{H}_{\mathbf{2}} \mathbf{L}$ forms $1: 1$ 296 complex with $\mathrm{Al}^{3+}$ ions (Fig. S15-16). To determine the binding stoichiometry of $\mathbf{H}_{2} \mathbf{L}$ and $\mathrm{Al}^{3+}$ 297 fluorescence intensity is plotted against different mole fractions of $\mathrm{Al}^{3+}$ while volume of solution 298 has remained constant (Fig. S16). Maxima in this plot has been obtained at 0.5 mole fraction, 299 which suggests about $1: 1$ complex formation of $\mathbf{H}_{2} \mathbf{L}$ and $\mathrm{Al}^{3+}$. The formation of the complex 300 further confirmed from ESI Mass spectroscopy. Mass spectrum of $\mathbf{H}_{2} \mathbf{L}$ in the presence of $\mathrm{Al}^{3+}$ 301 shows peak $\mathrm{m} / \mathrm{z}$ at 575.25 which is corresponding to cationic part of the complex $\mathbf{1}[\mathrm{Al}(\mathrm{L})]^{+}$(Fig. 302 S10). The simulated pattern shows well agreement with that of experimental values (Fig. S17). 303 Experimental findings (absorption spectra and fluorescence spectra of $\mathrm{Al}^{3+}$ and other cations and 304 various anions with chemosensor $\mathbf{H}_{2} \mathbf{L}$ ) clearly revealed that $\mathbf{H}_{2} \mathbf{L}$ has strong affinity towards $305 \mathrm{Al}^{3+}$. Here $\mathrm{Al}^{3+}$ acts as strong Lewis acid which can simply binds with two phenoxido oxygen 306 atoms and two imine nitrogen atoms of the Schiff base ligand. Thus the chemosensor acts as a 307 tetradentate $\mathrm{N} 2 \mathrm{O} 2$ donor ligand and form a distorted tetrahedral complex with $\mathrm{Al}^{3+}$. Comparable 308 size of the inner-cavity of the chemosensor and $\mathrm{Al}^{3+}$ i.e. suitable size and high charge density of $309 \mathrm{Al}^{3+}$ permits strong interaction between $\mathbf{H}_{2} \mathbf{L}$ and the metal ion.

311 been given in Supplementary Information (Fig. 7). Fluorescence life time of $\mathbf{H}_{\mathbf{2}} \mathbf{L}$ is found to 312 quite low (1.324 ns). Fluorescence life time of $\mathbf{H}_{2} \mathbf{L}$ in presence of one eq. of $\mathrm{Al}^{3+}$, increases up 313 to 2.058 ns. Quantum yields of $\mathbf{H}_{2} \mathbf{L}$ and complex $\mathbf{1}$ are calculated using equation 2 and found to 314 be very low. These have been measured to be 0.00939 and 0.2133 , respectively (Table S1). It is 315 to be noted that although quantum yield of the complex is low but it is almost 22 folds greater 316 compared to free $\mathbf{H}_{\mathbf{2}} \mathbf{L}$. 
$317 \quad \Phi_{\mathrm{x}}=\Phi_{\mathrm{s}}\left(\frac{\mathrm{F}_{\mathrm{x}}}{\mathrm{F}_{\mathrm{s}}}\right)\left(\frac{\mathrm{A}_{\mathrm{s}}}{\mathrm{A}_{\mathrm{x}}}\right)$

318 Where $F_{x}, F_{s}$ are the wavelength integrated emission intensities of the samples and reference

319 (here reference is Coumarine); $\mathrm{A}_{\mathrm{s}}, \mathrm{A}_{\mathrm{x}}$ are the optical densities at their corresponding wavelengths

320 of excitation.

321 Free ligand upon excitation gives peak at $510 \mathrm{~nm}$. In presence of $\mathrm{Al}^{3+}$ there is a slight blue shift

$322 \sim 32 \mathrm{~nm}$ of intensity and emission peak observed at $478 \mathrm{~nm}$. Upon gradual addition of $\mathrm{Al}^{3+}$ to

$323 \quad \mathbf{H}_{2} \mathbf{L}$ a steady increase in emission intensity at $478 \mathrm{~nm}$ has been observed.

324 Sensitivity of $\mathbf{H}_{2} \mathbf{L}$ towards $\mathrm{Al}^{3+}$ has been checked by determining limit of detection

325 (LOD) value. The detection limit of the chemosensor was calculated using $3 \sigma \operatorname{method}^{51}$ and it is

326 found to be $6.93 \times 10^{-9} \mathrm{~mol} / \mathrm{L} \cdot{ }^{14 \mathrm{e}} \mathrm{Low} \mathrm{LOD}$ value clearly indicate high sensitivity of $\mathbf{H}_{2} \mathbf{L}$ towards

$327 \mathrm{Al}^{3+}$ ion. In Table S1 some recently published chemosensors for $\mathrm{Al}^{3+}$ ion has been reported along

328 with their LOD values. ${ }^{14 a, 14 e, 14 \mathrm{~g}, 14 \mathrm{i}-140}$ The reported chemosensor has some advantages over the

329 others while it has some draw backs also. Our probe is synthesized by easy single step Schiff

330 base condensation process. LOD value is significantly low but not the lowest among all.

331 We also examined fluorescence intensity of $\mathbf{H}_{2} \mathbf{L}$ in absence and presence of $\mathrm{Al}^{3+}$ ion at

332 various $\mathrm{pH}$ values. We have maintained the $\mathrm{pH}$ range from 3 to 10 . The solution concentration of

333 both $\mathbf{H}_{2} \mathbf{L}$ and $\mathrm{Al}^{3+}$ is $10 \mu \mathrm{M}$ respectively. It has been observed that the chemosensor in free

334 condition exhibit very little fluorescence in the acidic condition $\left(\mathrm{p}^{\mathrm{H}}=3\right.$ to $\left.\mathrm{p}^{\mathrm{H}}=7\right)$. Fluorescence

335 intensity remains unchanged within this $\mathrm{p}^{\mathrm{H}}$ range. Upon increasing $\mathrm{pH}$ from 7 to 10 a slight

336 increase in fluorescence intensity has been observed. In presence of $\mathrm{Al}^{3+}$, in acidic condition $\left(\mathrm{p}^{\mathrm{H}}\right.$

$337=3$ to $\mathrm{p}^{\mathrm{H}}=5$ ) fluorescence intensity of the chemosensor remain unchanged due to protonation of

338 phenolic hydroxyl group of the ligand, therefore nullifying chelation ability with $\mathrm{Al}^{3+}$. $\mathrm{Al}^{3+}$ ion 
339 sensing abilities were exhibited by the ligand when $\mathrm{pH}$ was increased from 5.0 to 8.0. Thus, $\mathbf{H}_{2} \mathbf{L}$

340 exhibited good fluorescence sensing ability towards $\mathrm{Al}^{3+}$ ion over a wide range of $\mathrm{p}^{\mathrm{H}}$ (Fig. 8).

341 Based on the experimental results we can conclude that our chemosensor can be utilized as a

342 selective fluorescent probe to recognize and distinguish $\mathrm{Al}^{3+}$ ion in presence of other metal ions

343 in biological system under physiological condition.

\section{DFT study}

345 Geometry optimization of both $\mathbf{H}_{2} \mathbf{L}$ and $[\mathrm{Al}(\mathrm{L})]^{+}$has been performed using DFT/B3LYP

346 method. Mass spectral data analysis has confirmed that the composition of the complex ion is

$347[\mathrm{Al}(\mathrm{L})]^{+}$. The energy minimized structure of both $\mathbf{H}_{2} \mathbf{L}$ and $[\mathrm{Al}(\mathrm{L})]^{+}$are shown in Fig 9. Some

348 selected bond distances and bond angles of the optimized geometries of $[\mathrm{Al}(\mathrm{L})]^{+}$are listed in

349 Table 3. DFT optimized structure reveals that $\mathrm{Al}^{3+}$ is tetra-coordinated and distorted tetrahedral

350 in geometry (Fig. 9) where the chemosensor $\mathbf{H}_{2} \mathbf{L}$ act as a N2O2 donor center and binds to $\mathrm{Al}^{3+}$

351 through phenolic-O atom and imine-N. Theoretically calculated Al-N(imine) and Al-

$352 \mathrm{O}$ (phenolato) distances are around $1.906 \AA$ and $1.326 \AA$, respectively and have been comparable

353 with similar structure. ${ }^{14 \mathrm{e}}$ It is interesting to mention that upon complex formation the $\mathrm{C}(15)-$

$354 \mathrm{~N}(3), \mathrm{C}(17)-\mathrm{N}(4), \mathrm{C}(1)-\mathrm{O}(1)$ and $\mathrm{C}(20)-\mathrm{O}(2)$ bond distances have been significantly elongated

355 compared to free ligand (Table 3). Theoretical calculations show that electron density in both

356 HOMO and LUMO of $\mathbf{H}_{\mathbf{2}} \mathbf{L}$ is mainly distributed on the one part of the aromatic moiety. In metal

357 complex ion i.e. $[\mathrm{Al}(\mathrm{L})]^{+}$electron density in both HOMO and LUMO is allocated over the entire

358 ligand system. Energy of some selected M.O. of both $\mathbf{H}_{2} \mathbf{L}$ and $[\mathrm{Al}(\mathrm{L})]^{+}$are given in Table S3.

359 Mulliken charge distribution shows positive charge on aluminium ion i.e. 1.227343. Mulliken

360 charge distribution of $[\mathrm{Al}(\mathrm{L})]^{+}$is provided in Table $\mathrm{S} 4$. 
362

363

364

365

366

367

368

369

370

371

372

373

374

375

376

377

378

379

380

381

382

383

\section{TDDFT study}

For better understanding of electronic transition, TDDFT calculations were performed using B3LYP/CPCM method using same basis sets in acetonitrile. The calculated electronic transitions are given in Table 4. $\mathbf{H}_{2} \mathbf{L}$ shows intense absorption band for ligand based $n-\pi$ and $\pi-$ $\pi^{*}$ transitions around $290 \mathrm{~nm}$ and $388 \mathrm{~nm}$ respectively. The band at $290 \mathrm{~nm}$ is due to the contribution of $\mathrm{HOMO}-4 \rightarrow \mathrm{LUMO}+1$ and $\mathrm{HOMO} \rightarrow \mathrm{LUMO}+2$ transitions, whereas the band at $388 \mathrm{~nm}$ is due to the contribution of HOMO- $\rightarrow$ LUMO, HOMO $-1 \rightarrow$ LUMO+1 and $\mathrm{HOMO} \rightarrow$ LUMO transitions. For the $\mathrm{L}-\mathrm{Al}$ species the intense absorption band around $375 \mathrm{~nm}$ corresponding to $\mathrm{HOMO} \rightarrow \mathrm{LUMO}+1, \mathrm{HOMO} \rightarrow \mathrm{LUMO}+2, \mathrm{HOMO} \rightarrow \mathrm{LUMO}+3$ and $\mathrm{HOMO}-2$ $\rightarrow$ LUMO transitions (Fig. 10). The spectra calculated for the ligand and L-Al species were found to be compatible with those obtained experimentally. It is important to mention that in case of $[\mathrm{Al}(\mathrm{L})]^{+}$species all transitions are ligand based.

In order to have better understanding of the emission spectrum we have optimized the triplet state (T1) of both ligand $\left(\mathbf{H}_{2} \mathbf{L}\right)$ and $\left([\mathrm{Al}(\mathrm{L})]^{+}\right)$using same basis set. The emission wavelength obtained from the computation is very much comparable with that of experimental data. The data i.e. emission wavelength, emission energies and the nature of the transition obtained from the computation are given in Table 5. The emission band of the chemosensor $\left(\mathbf{H}_{2} \mathbf{L}\right)$ at $510 \mathrm{~nm}$ was theoretically obtained at $509.84 \mathrm{~nm}$ with major key transitions of $\operatorname{HOMO}(\alpha) \rightarrow \operatorname{LUMO}(\alpha)+1(58 \%), \operatorname{HOMO}(\alpha) \rightarrow \operatorname{LUMO}(\alpha)+2(10 \%)$ and $\operatorname{HOMO}(\beta)-1 \rightarrow \operatorname{LUMO}(\beta)$ (11\%) respectively. Whereas for the $[\mathrm{Al}(\mathrm{L})]^{+}$the emission band at $478 \mathrm{~nm}$ was theoretically obtained at 476.93 with major key transitions viz. $\operatorname{HOMO}(\beta) \rightarrow \operatorname{LUMO}(\beta)+2(22 \%)$ and $\operatorname{HOMO}(\alpha)-1 \rightarrow \operatorname{LUMO}(\alpha)(66 \%)$ respectively. 


\section{NMR studies}

Firstly, the chemosensor was well characterized in $\mathrm{CDCl}_{3}$ solvent. In $\mathrm{CDCl}_{3}$, imine

387 proton appeared at $8.43 \mathrm{ppm}$. Aromatic, aliphatic and methoxy protons appeared at 7.42-7.90 388 ppm, 3.82-3.84 ppm, $2.25 \mathrm{ppm}$ and $4.01 \mathrm{ppm}$ respectively. Then, we have performed ${ }^{1} \mathrm{H}$ NMR 389 studies of both free $\mathbf{H}_{2} \mathbf{L}$ and $\mathbf{H}_{2} \mathbf{L}+\mathrm{Al}^{3+}$ in 1:1 molar ratio in DMSO-d ${ }_{6}$ solvent (Fig. 11). The

390 free chemosensor $\left(\mathbf{H}_{\mathbf{2}} \mathbf{L}\right)$ exhibit clear peaks for different protons. Imine proton appears at 8.66 $391 \mathrm{ppm}$. All aromatic protons appear as multiplate at around 7.74-7.30 ppm. Aliphatic protons 392 appear as multiplate at 3.74 and $2.06 \mathrm{ppm}$ respectively. $-\mathrm{OCH}_{3}$ protons appear around $3.74 \mathrm{ppm}$. 393 In NMR spectrum signal of aliphatic one $-\mathrm{CH}_{2}$ got merged with that the signal of $-\mathrm{OCH}_{3}$. 394 Unfortunately we could not identify signal for phenolic $\mathrm{OH}$ proton due to extensive hydrogen 395 bonding with solvent molecules. Upon addition of $\mathrm{Al}^{3+}$ to the chemosensor peak positions of 396 different protons have changed significantly. Imine protons have shifted notably from $8.66 \mathrm{ppm}$ 397 to $9.24 \mathrm{ppm}$ indicating coordination of imine nitrogen with aluminium ion. In case of aromatic 398 and aliphatic protons broadening and overlapping of signals observed. Therefore, formation of 399 complex 1 in the presence of $\mathrm{Al}^{3+}$ is strongly evidenced from the NMR spectral studies.

\section{Molecular logic gates}

402 The property of this chemosensor encourages us to construct a molecular logic gate with 403 two binary inputs. The two inputs are $\mathrm{Al}^{3+}$ and $\mathrm{Na}_{2}$ EDTA where the output is monitored as 404 change in fluorescence emission spectrum at $478 \mathrm{~nm}$. In absence of both of the inputs there is no 405 significant change in emission band which implies that the gate is 'OFF'. On addition of $406 \mathrm{Na}_{2}$ EDTA to the chemosensor there is no significant changes, rather the emission band remained 
407 unchanged. So, in presence of $\mathrm{Na}_{2}$ EDTA the output was considered to be zero. On the other 408 hand, upon addition of $\mathrm{Al}^{3+}$ ion solution alone to the chemosensor shows significant 409 enhancement of the fluorescence intensity at $478 \mathrm{~nm}$ and now the output signal is 1 i.e. the gate 410 is 'ON'. However in presence of both of the inputs the fluorescence intensity is significantly 411 quenched and the output is zero implying that the gate is 'OFF' again. These studies suggest that 412 this molecular gate is acting as INHIBIT (INH) logic gate where the inputs and output are $\mathrm{Al}^{3+}$, $413 \mathrm{Na}_{2}$ EDTA and change in fluorescence intensity at $478 \mathrm{~nm}$, respectively. It is basically an 'AND' 414 gate which has one of its inputs is negated. The input which is negated, acts to inhibit the gate. 415 We can say that the gate will behave like an 'AND' gate only when the negated input is set at a 416 logic level ' 0 '. Here the negated input is $\mathrm{Na}_{2}$ EDTA. The respective truth table and pictorial 417 diagram of the INH logic gate is depicted in Fig.12 and Table 6.

\section{Conclusion}

419 In summary, an azo based low cost, simple, easy to prepare, chemosensor $\mathbf{H}_{2} \mathbf{L}$ has been 420 successfully prepared which is capable of recognizing $\mathrm{Al}^{3+}$ ion in presence of large number of 421 other metal ions in HEPES buffer solution (1:100 v/v, HEPES buffer at pH 7.4) at $25^{\circ} \mathrm{C}$. The 422 chemosensor has been structurally characterized. Fluorescence intensity of the probe has 423 enhanced by $\sim 61$ fold in presence of $\mathrm{Al}^{3+}$. The low detection limit of $\mathbf{H}_{2} \mathbf{L}$ for $\mathrm{Al}^{3+}(6.93 \mathrm{nM})$ 424 suggests that the chemosensor could be a good choice for efficient monitoring of the $\mathrm{Al}^{3+}$ in real 425 samples. $\mathbf{H}_{2} \mathbf{L}$ forms 1:1 complex with $\mathrm{Al}^{3+}$ which has been established by 1H NMR, MS studies 426 and further supported by DFT calculations. $\mathbf{H}_{\mathbf{2}} \mathbf{L}$ exhibited good fluorescence sensing ability 427 towards $\mathrm{Al}^{3+}$ ion over a wide range of $\mathrm{p}^{\mathrm{H}}$, therefore, $\mathbf{H}_{2} \mathbf{L}$ could be successfully applied to living 428 cells for detecting $\mathrm{Al}^{3+}$. We also establish Molecular logic gates (INH) based on two inputs $\left(\mathrm{Al}^{3+}\right.$ 
429 and EDTA)and one Output. Thus, this probe could be considered as a potential candidate for

430 sensing $\mathrm{Al}^{3+}$ in less organic solvents.

432 Acknowledgments

433 A. S. gratefully acknowledges the financial support of this work by the DST, India (Sanction No.

434 SB/FT/CS-102/2014, dated- 18.07.2015). The authors are thankful to Prof. Mahammad Ali and

435 Mr. Pravat Ghorai, Department of Chemistry, Jadavpur University, India for their scientific

436 suggestions. The authors also acknowledge the use of the DST-funded National Single Crystal X-

437 ray Diffraction Facility at the Department of Chemistry, Jadavpur University, Kolkata-700032,

438 India for X-ray crystallographic studies.

440 Appendix A. Supplementary data

441 CCDC 1478332-1478333 contain the supplementary crystallographic data for azoaldehyde and $442 \mathbf{H}_{2} \mathbf{L}$. This data can be obtained free of charge via 443 http://www.ccdc.cam.ac.uk/conts/retrieving.html, or from the Cambridge Crystallographic Data 444 Centre, 12 Union Road, Cambridge CB2 1EZ, UK; fax: (+44) 1223-336-033; or 445 email:deposit@ccdc.cam.ac.uk.

446 Notes and References

$447{ }^{a}$ Department of Chemistry, Jadavpur University, Kolkata- 700032, India.

448 E-mail:asaha@chemistry.jdvu.ac.in; amritasahachemju@gmail.com; Tel.+91-33-24572941

$449{ }^{b}$ TEMA-NRD, Mechanical Engineering Department, University of Aveiro, 3810-193 Aveiro, 450 Portugal 


\section{References}

4561 M. G. Sont, S. M. White, W. G. Flamm and G. A. Burdock, Regul. Toxicol. Pharmacol., 2001, $457 \quad 33,66-79$.

458 2(a) D. R. Crapper, S. S. Krishnan and A. J. Dalton, Science, 1973, 180, 511-513; (b) D. P. Perl 459 and A. R. Brody, Science, 1980, 208, 297-299; (c) E. House, J. Collingwood, A. Khan, O. 460 Korchazkina, G. Berthon and C. J. Exley, J. Alzheimers Dis., 2004, 6, 291-301.

4613 G.C. Woodson, Bone, 1998, 22, 695-698.

4624 P.D. Darbre, J. Inorg. Biochem., 2005, 99,1912-1919.

4635 R. W. Gensemer and R. C. Playle, Crit. Rev. Environ. Sci. Technol., 1999, 29, 315-450.

464 6(a) A. Budimir, Acta Pharm., 2011, 61, 1; (b) P. Nayak, Environ. Res., 2002, 89, 101-115; (c) 465 P. Zatta, Coord. Chem. Rev., 2002, 228, 271-284.

4667 (a) J. Barcelo and C. Poschenrieder, Environ. Exp. Bot., 2002, 48, 75-92; (b) B. Valeur and I. 467 Leray, Coord. Chem. Rev., 2000, 205, 3-40; (c) Z. Krejpcio and R. W. P. J. Wojciak, Environ. 468 Stud., 2002, 11, 251-254.

4698 K. Soroka, R. S. Vithanage, D. A. Phillips, B. Walker and P. K. Dasgupta, Anal. Chem., 1987, $470 \quad 59,629-636$.

4719 A. Zioła-Frankowska, M. Frankowski and J. Siepak, Talanta, 2009, 79, 623-630.

47210 F. Zheng and B. Hu, Spectrochim. Acta, Part B, 2008, 63, 9-10.

47311 F. Thomas, A. Maslon, J. Y. Bottero, J. Rouiller, F. Montlgny and F. Genevrlere, Environ. 474 Sci. Technol., 1993, 27, 2511-2516. 
47512 Y. H. Ma, R. Yuan, Y. Q. Chai and X. L. Liu, Mater. Sci. Eng., 2010, 30, 209-224.

47613 K. Soroka, R. S.Vithanage, D. A. Phillips, B. Walker and P. K. Dasgupta, Anal. Chem., 1987, 477 59, 629-636.

47814 (a) L. Wang, W. Qin, X. Tang, W. Dou, W. Liu, Q. Teng and X. Yao, Org. Biomol.Chem., 479 2010, 8, 3751-3157; (b) K. K. Upadhyay and A. Kumar, Org. Biomol. Chem., 2010, 8, 4892480 4897; (c) F. K. Hau, X. He, W. H. Lam and V. W. Yam, Chem. Commun., 2011, 47, 8778-8780; 481 (d) A. Sahana, A. Banerjee, S. Das, S. Lohar, D. Karak, B. Sarkar, S. K. Mukhopadhyay, A. K. 482 Mukherjee and D. Das, Org. Biomol.Chem., 2011, 9, 5523-5529; (e) A. Banerjee, A. Sahana, S. 483 Das, S. Lohar, S. Guha, B. Sarkar, S. K. Mukhopadhyay, A. K. Mukherjee and D. Das, Analyst, 484 2012, 137, 2166-2175; (f) D. Karak, S. Lohar, A. Sahana, S. Guha, A. Banerjee and D. Das, Anal 485 Methods, 2012, 4, 1906-1908; (g) D. Karak, S. Lohar, A. Banerjee, A. Sahana, I. Hauli, S. K. 486 Mukhopadhyay, J. S. Matalobos and D. Das, RSC $A d v ., 2012,2,12447-12454$; (h) A. Sahana, A. 487 Banerjee, S. Lohar, S. Das, I. Hauli, S. K. Mukhopadhyay, J. S. Matalobos and D. Das, Inorg. 488 Chim. Acta, 2012, 12, 12-13.(i) A. Sahana, A. Banerjee, S. Lohar, B. Sarkar, S.K. 489 Mukhopadhyay and D. Das, Inorg. Chem., 2013, 52, 3627-3633 and references cited herein; (j) 490 D. Maity and T. Govindaraju, Inorg. Chem., 2010, 49, 7229-7231; (k) J. Ma, W. Shi, L. Feng, 491 Y. Chen, K. Fan, Y. Hao, Y. Hui A and Z. Xie, RSC Advances, 2016, 2016, 6, 28034-28037; (1) 492 B. Sen, M. Mukherjee, S. Banerjee, S. Pala and P. Chattopadhyay, Dalton trans., 2015, 44, 8708493 8717; (m) J. Kumar, M. J. Sarma, P. Phukan and D. K. Das, Dalton Trans., 2015, 44, 4576494 4581; (n) C. Kar, S. Samanta, S. Goswami, A. Ramesh and G. Das, Dalton trans., 2015, 44, 495 4123-4132; (o) S. Goswami, K. Aich, S. Das, A. Kumar Das, D. Sarkar, S. Panja, T.K. Mondal 496 and S. Mukhopadhyay, Chem. Commun., 2013, 49, 10739-10741; (p) A. Roy, S. Dey and Partha 497 Roy, Sensors and Actuators B, 2016,B 237, 628-642 and references cited herein. 
49915 (a) Z. Xu, Y. Xiao, X. Qian, J. Cui and D. Cui, Org. Lett., 2005, 7, 889. (b) J. B. Wang, X. F.

500 Qian and J. N. Cui, J. Org. Chem., 2006, 71, 4308-4311.

50116 (a) T. Gunnlaugsson, A. P. Davis, J. E. O’Brien and M. Glynn, Org. Lett., 2002, 4, 2449-

502 2452; (b) D. H. Vance and A. W. Czarnik, J. Am. Chem. Soc., 1994, 116, 9397-9398; (c) S. K.

503 Kim and J. Yoon, Chem. Commun., 2002, 770-771.

50417 (a) N. C. Lim, J. V. Schuster, M. C. Porto, M. A. Tanudra, L. Yao, H. C. Freake and C. 505 Bruckner, Inorg. Chem., 2005, 44, 2018-2030; (b) S. Guha, S. Lohar, A. Banerjee, A. Sahana, A. 506 Chaterjee, S. K. Mukherjee, J. S. Matalobos and D. Das, Talanta, 2012, 91, 18-25; (c) S. Das, A. 507 Sahana, A. Banerjee, S. Lohar, S. Guha, J. S. Matalobos and D. Das, Anal. Methods, 2012, 4, $508 \quad 2254-2258$.

50918 (a) P. D. Beer, Acc. Chem. Res., 1998, 31, 71-80; (b) M. J. Kim, R. Konduri, H. Ye, F. M.

510 MacDonnell, F. Puntoriero, S. Serroni, S. Campagna, T. Holder, G. Kinsel and K. Rajeshwar, 511 Inorg. Chem., 2002, 41, 2471-2476.

51219 (a) S. Nishizawa, Y. Kato and N. Teramae, J. Am. Chem. Soc., 1999, 121, 9463-9464; (b) J.513 S. Wu, J.-H. Zhou, P.-F. Wang, X.-H. Zhang and S.- K. Wu, Org. Lett., 2005, 7, 2133-2136; (c) 514 B. Schazmann, N. Alhashimy and D. Diamond, J. Am. Chem. Soc., 2006, 128, 8607-8614; (d) A. 515 Banerjee, A. Sahana, S. Guha, S. Lohar, I. Hauli, S. K. Mukhopadhyay, J. S. Matalobos and D. 516 Das, Inorg. Chem., 2012, 51, 5699-5704; (e) A. Sahana, A. Banerjee, S. Lohar, S. Guha, S. Das, 517 S. K. Mukhopadhyay and D. Das, Analyst, 2012, 137, 3910-3913.

51820 J.-S. Wu, W.-M. Liu, X.-Q. Zhuang, F. Wang, P.-F. Wang, S.-L. Tao, X.-H. Zhang, S.-K. Wu 519 and S.-T. Lee, Org. Lett., 2007, 9, 33-36. 
52021 (a) A. Sahana, A. Banerjee, S. Guha, S. Lohar, A. Chattopadhyay, S. K. Mukhopadhyay and 521 D. Das, Analyst, 2012, 137, 1544-1546; (b) S. Lohar, A. Sahana, A. Banerjee, A. Banik, S. K. 522 Mukhopadhyay, J. S. Matalobos and D. Das, Anal. Chem., 2013, 85, 1778-1783; (c) S. Das, S. 523 Guha, A. Banerjee, S. Lohar, A. Sahana and D. Das, Org. Biomol. Chem., 2011, 9, 7097-7104.

52422 X. Peng, Y. Wu, J. Fan, M. Tian and K. Han, J. Org. Chem., 2005, 70, 10524-10531.

52523 (a) J. M. Serin, D. W. Brousmiche and J. M. J. Frechet, J. Am. Chem. Soc., 2002, 124, 11848526 11849; (b) A. E. Albers, V. S. Okreglak and C. J. Chang, J. Am. Chem. Soc., 2006, 128, 9640527 9641; (c) S. H. Lee, S. K. Kim, J. H. Bok, S. H. Lee, J. Yoon, K. Lee and J. S. Kim, Tetrahedron 528 Lett., 2005, 46, 8163-8167; (d) W. R. Dichtel, J. M. Serin, C. Edder, J. M. J. Frechet, M. 529 Matuszewski, L.-S. Tan, T. Y. Ohulchanskyy and P. N. Prasad, J. Am. Chem. Soc., 2004, 126, 530 5380-5381; (e) M. Suresh, S. Mishra, S. K. Mishra, E. Suresh, A. K. Mandal, A. Shrivastav, A. 531 Das, Org. Lett., 2009, 11, 2740-2743; (f) P.Mahato, S.Saha, E.Suresh, R. D.Liddo, P. P. 532 Parnigotto, M. T. Conconi, M. K. Kesharwani, B. Ganguly and A. Das, Inorg. Chem., 2012, 51, 533 1769-1777; (g) K. Sreenath, J. Allen, R. M. W. Davidsonand L. Zhu, Chem. Commun., 2011, 47, 534 11730-11732;(h) R. J.Wandell, A. H.Younes and L. Zhu, New J. Chem.,2010, 34, 2176-2182; (i) 535 S. Lohar, A. Banerjee, A. Sahana, A. Banik, S. K. Mukhopadhyay and D. Das, Anal Methods, $5362013, \mathbf{5}, 442-445$.

53724 (a) A. Natansohn and P. Rochon, Chem. Rev., 2002, 102, 4139-4176; (b) A. S. Matharu, S. 538 Jeeva and P. S. Ramanujam, Chem. Soc. Rev., 2007, 36, 1868-1880; (c) T. Ikeda, J. Mater. 539 Chem., 2003, 13, 2037-2057; (d) S. Kubo, Z. Z. Gu, K. Takahashi, A. Fujishima, H. Segawa and 540 O. Sato, J. Am. Chem. Soc., 2004, 126, 8314-8319; (e) C. Dohno, S. N. Uno and K. Nakatani, J. 541 Am. Chem. Soc., 2007, 129, 11898-11899; (f ) N. Kano, F. Komatsu, M. Yamamura and T. 
542 Kawashima, J. Am. Chem. Soc., 2006, 128, 7097-7106; (g) A. Archut, F. Vogtle, L. De Cola, G.

543 C. Azzellini, V. Balzani, P. S. Ramanujam and R. H. Berg, Chem.-Eur. J., 1998, 4, 699-706.

54425 A. Abbotto, L. Beverina, N. Manfredi, G. A. Pagani, G. Archetti, H. G. Kuball, C.

545 Wittenburg, J. Heck and J. Holtmann, Chem.-Eur. J., 2009, 15, 6175-6185.

54626 S. Kawata and Y. Kawata, Chem. Rev., 2000, 100, 1777-1788.

54727 Y. T. Li, C. L. Chen, Y. Y. Hsu, H. C. Hsu, Y. Chi, B. S. Chen, W. H. Liu, C. H. Lai, T. Y.

548 Lin and P. T. Chou, Tetrahedron, 2010, 66, 4223-4229.

54928 X. C. Chen, T. Tao, Y. Ge Wang, Y. X. Peng, W. Huang and H. F. Qian, Dalton Trans., $550 \quad 2012,41,11107-11115$.

55129 (a) M. E. Moustafa, M. S. McCready and R. J. Puddephatt, Organometallics, 2012, 31, 6262-

552 6269; (b) M. E. Moustafa, M. S. McCready and R. J. Puddephatt, Organometallics, 2013, 32, 553 2552-2557; (c) G. C. Hampson and M. Robertson, J. Chem. Soc., 1941, 409-413.

55430 A. Kumar, A. Kumar and D.S. Pandey, Dalton Trans., 2016, 45, 8475-8484.

55531 G.M. Sheldrick, SAINT, Version 6.02, SADABS, Version 2.03, Bruker AXS Inc., Madison, 556 Wisconsin, 2002.

55732 G.M. Sheldrick, SADABS: Software for Empirical Absorption Correction, University of 558 Gottingen, Institute fur Anorganische Chemieder Universitat, Gottingen, Germany, 1999-2003.

55933 G. M. Sheldrick, Acta Cryst., 2008, A64, 112-122.

56034 M.J. Frisch, G.W. Trucks, H.B. Schlegel, G.E. Scuseria, M.A. Robb, J.R. Cheeseman, G. 561 Scalmani, V. Barone, B. Mennucci, G.A. Petersson, H. Nakatsuji, M. Caricato, X. Li, H.P. 562 Hratchian, A.F. Izmaylov, J. Bloino, G. Zheng, J.L. Sonnenberg, M. Hada, M. Ehara, K. Toyota, 563 R. Fukuda, J. Hasegawa, M. Ishida, T. Nakajima, Y. Honda, O. Kitao, H. Nakai, T. Vreven, J.A. 564 Montgomery Jr. J.E. Peralta, F. Ogliaro, M. Bearpark, J.J. Heyd, E. Brothers, K.N. Kudin, V.N. 
565 Staroverov, R. Kobayashi, J. Normand, K. Raghavachari, A. Rendell, J.C. Burant, S.S. Iyengar,

566 J. Tomasi, M. Cossi, N. Rega, J.M. Millam, M. Klene, J.E. Knox, J.B. Cross, V. Bakken, C.

567 Adamo, J. Jaramillo, R. Gomperts, R.E. Stratmann, O. Yazyev, A.J. Austin, R. Cammi, C.

568 Pomelli, J.W. Ochterski, R.L. Martin, K. Morokuma, V.G. Zakrzewski, G.A. Voth, P. Salvador,

569 J.J. Dannenberg, S. Dapprich, A.D. Daniels, Ö. Farkas, J.B. Foresman, J.V. Ortiz, J. Cioslowski,

570 D.J. Fox,GAUSSIAN09, Revision D.01, Gaussian Inc. Wallingford, CT, 2009.

57135 A. D. Becke, J. Chem. Phys., 1993, 98, 5648-5652.

57236 C. Lee, W. Yang and R.G. Parr, Phys. Rev., 1988, B 37, 785-789.

57337 P.J. Hay and W.R. Wadt, J. Chem. Phys., 1985, 82, 270-283.

57438 W.R. Wadt and P.J. Hay, J. Chem. Phys., 1985, 82, 284-298.

57539 P.J. Hay and W.R. Wadt, J. Chem. Phys., 1985, 82, 299-310.

57640 G.A. Petersson, A. Bennett, T.G. Tensfeldt, M.A. Al-Laham, W.A. Shirley and J. Mantzaris, 577 J. Chem. Phys., 1988, 89, 2193-2218.

57841 G.A. Petersson and M.A. Al-Laham, J. Chem. Phys., 1991, 94, 6081-6090.

57942 R. Bauernschmitt and R. Ahlrichs, Chem. Phys. Lett., 1996,256, 454-464.

580 43R. E. Stratmann, G. E. Scuseria and M. J. Frisch, J. Chem. Phys., 1998, 109, 8218-8224.

58144 M.E. Casida, C. Jamorski, K.C. Casida and D.R. Salahub, J. Chem. Phys., 1998, 108, 44395824449.

58345 V. Barone and M. Cossi, J. Phys. Chem. A, 1998, 102, 1995-2001.

58446 M. Cossi and V. Barone, J. Chem. Phys., 2001, 115, 4708-4717. 
58547 M. Cossi, N. Rega, G. Scalmani and V. Barone, J. Comput.Chem., 2003, 24, 669-681.

58648 N.M. O’Boyle, A.L. Tenderholt and K.M. Langner, J. Comput. Chem., 2008, 29, 839-845.

58749 M. T. Wheeler and F. Walmsley, ThermochimicaActu, 1986, 108, 325-336.

58850 G. Ozkan, M. Kose , H. Zengin, V. McKee and M. Kurtoglu, Spectrochimica Acta Part A:

589 Molecular and Biomolecular Spectroscopy, 2015, 150, 966-972.

590 51A. B. Pradhan, S. K. Mandal, S. Banerjee, A. Mukherjee, S. Das, A.R.K. Bukhsh and A.

591 Saha, Polyhedron, 2015, 94, 75-82.

592

593

594

595

596

597

598

599

600 

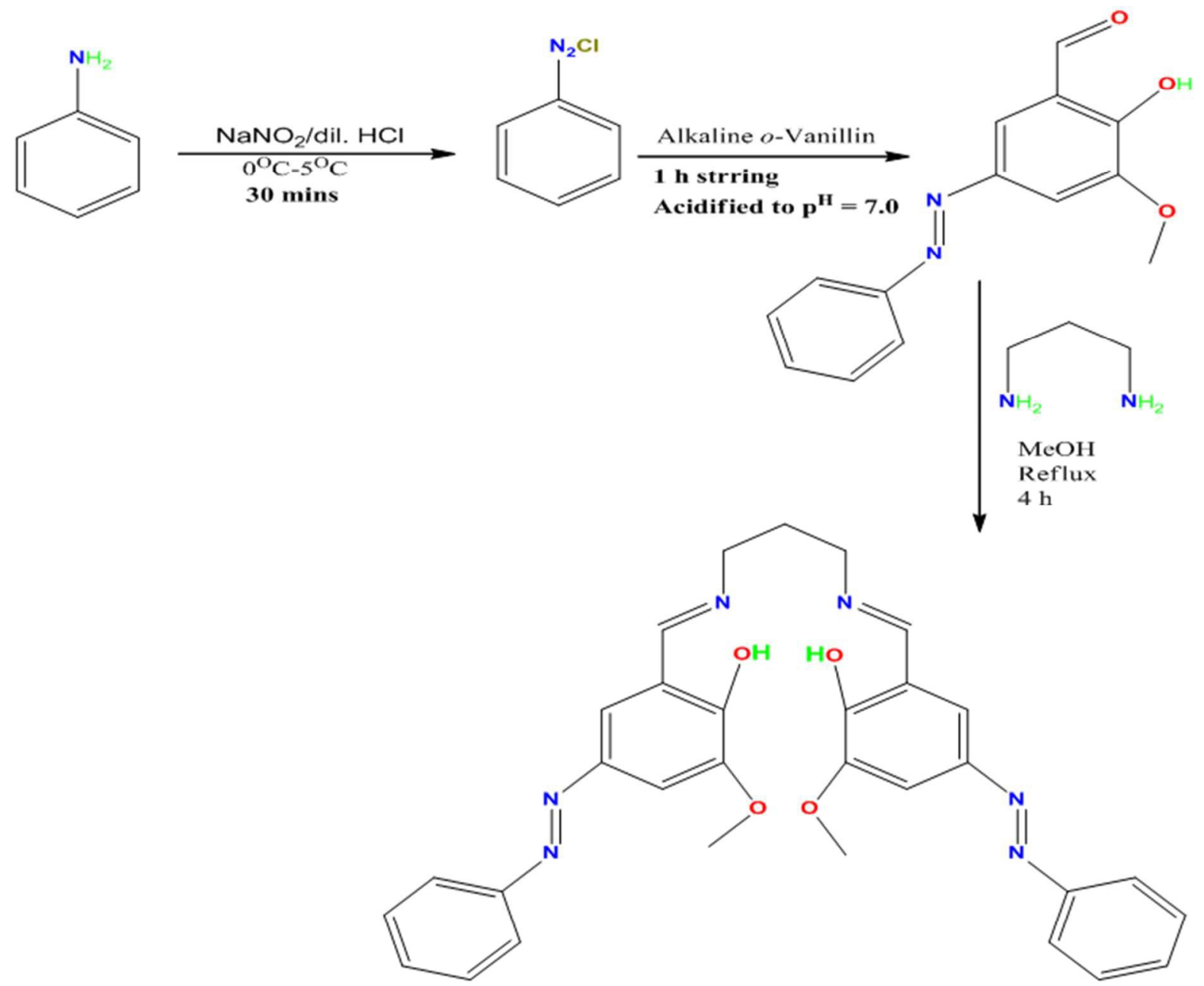

601

602

603 Scheme 1.The route to the syntheses of $\mathbf{H}_{2} \mathbf{L}$.

604

605

606

607

608

609 
610

611

612

613

614

615

616

617

618

$\lambda \mathrm{ex}=388 \mathrm{~nm}$

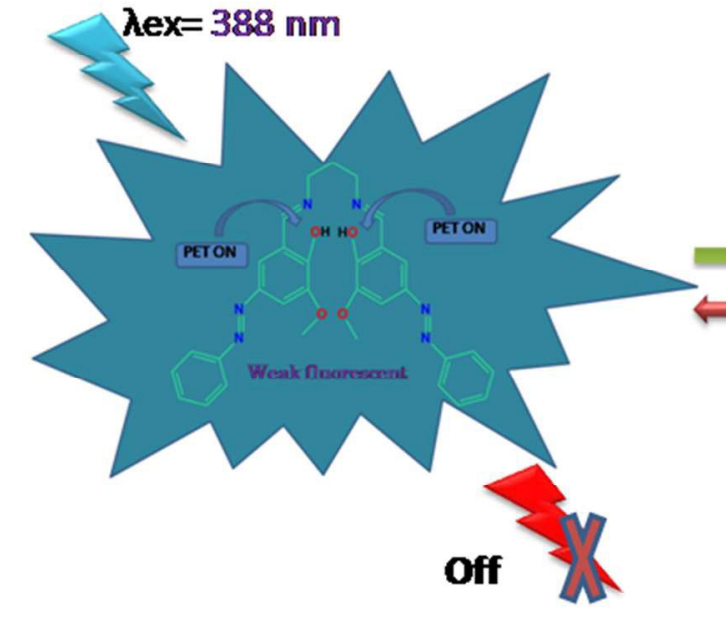

$\lambda \mathrm{ex}=375 \mathrm{~nm}$

13

4

15

16

619

619

620

621 Scheme 2. Schematic diagram for photoinduced electron transfer (PET) in free $\mathbf{H}_{2} \mathbf{L}$ and

622 chelation enhancement effect $(\mathrm{CHEF})$ in $[\mathrm{Al}(\mathrm{L})]^{+}$.

623

624

625

626

627

628

629

630

631

632 
634 Table 1. Crystal parameters and selected refinement details for $\mathbf{H}_{2} \mathbf{L}$.

\begin{tabular}{|c|c|c|}
\hline Compound & Azoaldehyde & $\mathrm{H}_{2} \mathrm{~L}$ \\
\hline Empirical formula & $\mathrm{C}_{14} \mathrm{H}_{12} \mathrm{~N}_{2} \mathrm{O}_{3}$ & $\mathrm{C}_{31} \mathrm{H}_{28} \mathrm{~N}_{6} \mathrm{O}_{4}$ \\
\hline Formula weight & 256.26 & 548.59 \\
\hline Temperature (K) & $155(2)$ & $150(2)$ \\
\hline Crystal system & Monoclinic & Triclinic \\
\hline Space group & $\mathrm{CC}$ & \\
\hline$a(\AA)$ & $10.7683(4)$ & $8.648(2)$ \\
\hline$b(\AA)$ & 13.4401(5) & 11.051(3) \\
\hline$c(\AA)$ & $8.4892(3)$ & $13.816(4)$ \\
\hline$\alpha\left(^{\circ}\right)$ & 90.00 & 91.833(9) \\
\hline$\beta\left(^{\circ}\right)$ & $93.755(2)$ & 97.710(9) \\
\hline$\gamma\left({ }^{\circ}\right)$ & 90.00 & 92.902(8) \\
\hline Volume $\left(\AA^{3}\right)$ & $1225.98(8)$ & $1305.8(6)$ \\
\hline Z & 4 & 2 \\
\hline$D_{\text {calc }}\left(\mathrm{g} \mathrm{cm}^{-3}\right)$ & 1.388 & 1.395 \\
\hline
\end{tabular}




\begin{tabular}{|l|l|l|}
\hline Absorption coefficient $\left(\mathrm{mm}^{-1}\right)$ & 0.100 & 0.095 \\
\hline$F(000)$ & 536 & 576 \\
\hline$\theta$ Range for data collection $\left(^{\circ}\right)$ & $2.43-26.40$ & $2.326-23.559$ \\
\hline Reflections collected & 4910 & 12084 \\
\hline Independent reflections / $\mathrm{R}_{\mathrm{int}}$ & $2204 / 0.0313$ & $3806 / 0.0726$ \\
\hline Observed reflections $[\mathrm{I}>2 \sigma(\mathrm{I})]$ & 1980 & 2308 \\
\hline Data / restraints / parameters & $2204 / 2 / 175$ & $3806 / 0 / 373$ \\
\hline Goodness-of-fit on $F^{2}$ & 1.029 & $\mathrm{~N} 1.752$ \\
\hline Final indices[I>2 $\sigma(\mathrm{I})]$ & $\mathrm{R} 1=0.0331$ & $\mathrm{wR} 2=0.4619$ \\
\hline Largest diff. peak / hole $\left(\mathrm{e} \AA^{-3}\right)$ & $0.150 /-0.120$ & $\mathrm{wR} 2=0.4280$ \\
\hline$R$ indices (all data) & $\mathrm{wR} 2=0.0812$ & $\mathrm{R} 1=0.1611$ \\
\hline & & \\
\hline
\end{tabular}

635

636

637

638 
639 Table 2. Selected bond lengths $(\AA)$ and bond angles $\left({ }^{\circ}\right)$ for Azoaldehyde and $\mathbf{H}_{2} \mathbf{L}$

640

641

642

643

644

645

646

647

648

649

650

651

\begin{tabular}{|c|c|c|c|c|c|}
\hline \multicolumn{3}{|c|}{ Azoaldehyde } & \multicolumn{3}{|c|}{$\mathrm{H}_{2} \mathrm{~L}$} \\
\hline & X-ray & Calculated & & X-ray & Calculated \\
\hline C3-O2 & 1.340 & 1.3450 & N1-N2 & $1.22(1)$ & 1.2645 \\
\hline C8-O1 & 1.224 & 1.2264 & N5-N6 & $1.267(9)$ & 1.2647 \\
\hline N1-N2 & 1.252 & 1.2611 & C15-N3 & $1.29(1)$ & 1.2853 \\
\hline C2-O3 & 1.362 & 1.3631 & C17-N4 & $1.28(1)$ & 1.2845 \\
\hline & & & C15-C16-C17 & $114.4(7)$ & 115.79 \\
\hline & & & $\mathrm{C} 1-\mathrm{O} 1$ & 1.259 & 1.275 \\
\hline & & & $\mathrm{C} 2-\mathrm{O} 2$ & 1.286 & 1.297 \\
\hline
\end{tabular}

652

653

654

655

656 
657 Table 3. Selected bond lengths $(\AA)$ and bond angles $\left({ }^{\circ}\right)$ of DFT optimized structure of $[\mathrm{Al}(\mathrm{L})]^{+}$.

$658 \quad(\mathrm{~B} 3 \mathrm{LYP} / 6-31+\mathrm{G}(\mathrm{d})$ basis set $)$

659

660

661

\begin{tabular}{|l|l|l|l|l|l|}
\hline & Calculated & & Calculated & & Calculated \\
\hline N1-N2 & 1.26019 & C1-O1 & 1.32767 & Al-O1 & 1.7584 \\
\hline N5-N6 & 1.26320 & C2-O2 & 1.32668 & Al-O2 & 1.7553 \\
\hline C15-N3 & 1.31355 & Al-N3 & 1.90639 & & \\
\hline C17-N4 & 1.31661 & Al-N4 & 1.92372 & & \\
\hline C15-C16-C17 & 115.79 & C15-C16-C17 & 116.50435 & & \\
& & & & & \\
\hline
\end{tabular}

662

663

664

665

666

667

668

669 
670 Table 4. Electronic transition calculated by TDDFT using B3LYP/CPCM method in Acetonitrile

671 solvent of Ligand $\left(\mathbf{H}_{2} \mathbf{L}\right)$ and $[\mathbf{A l}(\mathbf{L})]^{+}$.

672

\begin{tabular}{|c|c|c|c|c|c|}
\hline & $\begin{array}{c}\text { Eexcitation } \\
(\mathrm{ev})\end{array}$ & $\begin{array}{c}\lambda_{\text {excitation }} \\
(\mathrm{nm})\end{array}$ & $\begin{array}{c}\text { Osc. Strength } \\
\text { (f) }\end{array}$ & Key transition & Character \\
\hline \multirow{5}{*}{ 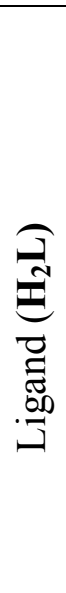 } & 3.60 & 344.43 & 0.1608 & $\mathrm{HOMO}-4 \rightarrow \mathrm{LUMO}+1(42 \%)$ & $\pi(\mathrm{L}) \rightarrow \pi^{*}(\mathrm{~L})$ \\
\hline & 3.57 & 346.63 & 0.0469 & $\mathrm{HOMO} \rightarrow \mathrm{LUMO}+2(29 \%)$ & $\pi(\mathrm{L}) \rightarrow \pi^{*}(\mathrm{~L})$ \\
\hline & 3.19 & 388.28 & 0.902 & HOMO-1 $\rightarrow$ LUMO (56\%) & $\pi(\mathrm{L}) \rightarrow \pi^{*}(\mathrm{~L})$ \\
\hline & 3.14 & 394.53 & 0.6101 & HOMO-1 $\rightarrow$ LUMO+1(48\%) & $\pi(\mathrm{L}) \rightarrow \pi^{*}(\mathrm{~L})$ \\
\hline & 3.019 & 410.64 & 0.0149 & $\mathrm{HOMO} \rightarrow \mathrm{LUMO}(71 \%)$ & $\pi(\mathrm{L}) \rightarrow \pi^{*}(\mathrm{~L})$ \\
\hline \multirow{4}{*}{ 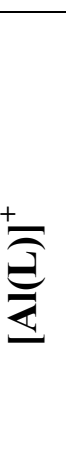 } & 3.17 & 390.79 & 0.2576 & HOMO-1 $\rightarrow$ LUMO+1(86\%) & $\pi(\mathrm{L}) \rightarrow \pi^{*}(\mathrm{~L})$ \\
\hline & 3.15 & 393.75 & 0.0254 & $\mathrm{HOMO} \rightarrow \mathrm{LUMO}+2(82 \%)$ & $\pi(\mathrm{L}) \rightarrow \pi^{*}(\mathrm{~L})$ \\
\hline & 3.02 & 411.01 & 0.0011 & HOMO- $1 \rightarrow$ LUMO (86\%) & $\pi(\mathrm{L}) \rightarrow \pi^{*}(\mathrm{~L})$ \\
\hline & 2.95 & 419.85 & 0.6153 & $\mathrm{HOMO} \rightarrow \mathrm{LUMO}(89 \%)$ & $\pi(\mathrm{L}) \rightarrow \pi^{*}(\mathrm{~L})$ \\
\hline
\end{tabular}

673

674

675 
676 Table 5. Emission spectrum calculated by TDDFT using B3LYP basis set for Ligand $\left(\mathbf{H}_{\mathbf{2}} \mathbf{L}\right)$ and $677 \quad[\mathrm{Al}(\mathrm{L})]^{+}$.

\begin{tabular}{|c|c|c|c|c|c|}
\hline & $\begin{array}{c}\mathrm{E}_{\text {excitation }} \\
\text { (ev) }\end{array}$ & $\lambda_{\text {emission }}(\mathrm{nm})$ & $\begin{array}{l}\text { Excited } \\
\text { State }\end{array}$ & Osc. Strength (f) & Key transition \\
\hline 兽 & 2.43 & 509.84 & 5 & 0.0116 & $\begin{array}{l}\operatorname{HOMO}(\alpha) \rightarrow \operatorname{LUMO}(\alpha)+1(58 \%) \\
\operatorname{HOMO}(\beta)-1 \rightarrow \operatorname{LUMO}(\beta)(11 \%) \\
\operatorname{HOMO}(\alpha) \rightarrow \operatorname{LUMO}(\alpha)+2(10 \%)\end{array}$ \\
\hline 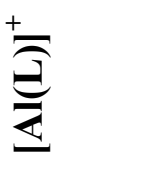 & 2.17 & 476.93 & 8 & 0.2476 & $\begin{array}{l}\operatorname{HOMO}(\alpha)-1 \rightarrow \operatorname{LUMO}(\alpha)(66 \%) \\
\operatorname{HOMO}(\beta) \rightarrow \operatorname{LUMO}(\beta)+2(22 \%)\end{array}$ \\
\hline
\end{tabular}

678

679

680

681

682

683

684

685

686

687 
690

691 Table 6.Truth Table

692

693

694

695

\begin{tabular}{|c|c|c|}
\hline IN1 & IN2 & Output (Emission at 478 nm) \\
\hline 0 & 0 & 0 \\
\hline 0 & 1 & 0 \\
\hline 1 & 0 & 1 \\
\hline 1 & 1 & 0 \\
\hline
\end{tabular}

700

701

702

703

704

705 
707

708

709

710

711

712

713

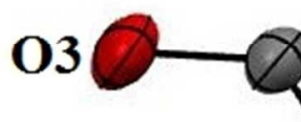

714

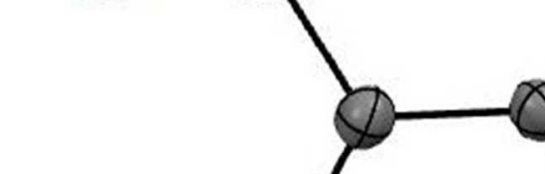

715

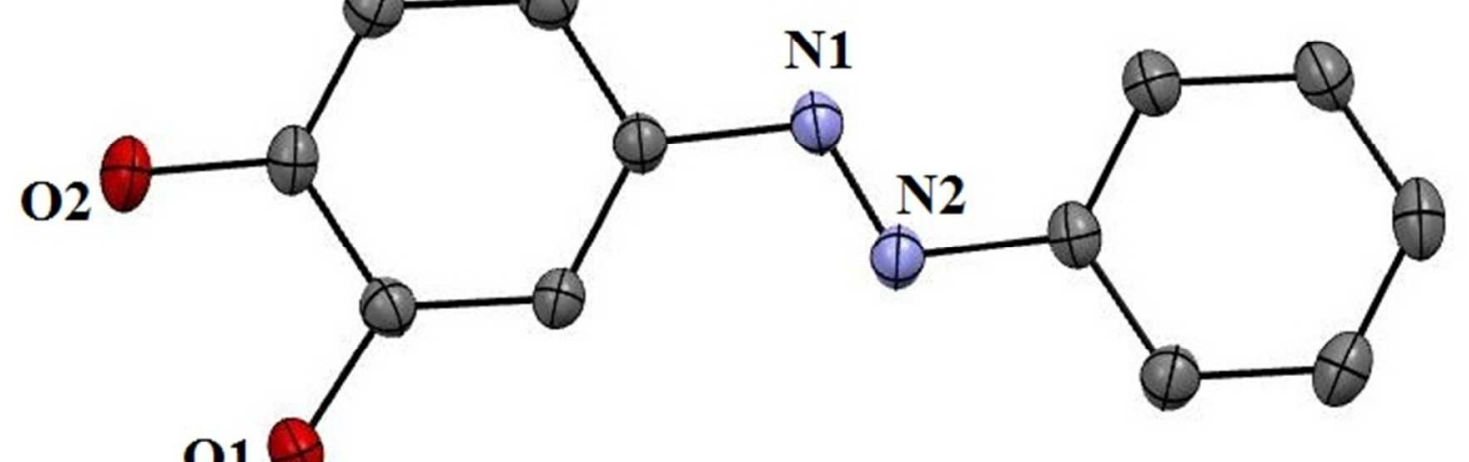

716

717

718

719

720

721

722

723

724 Fig. 1. Ortep view of azoaldehyde. Atoms are shown as 30\% thermal ellipsoids. H atoms are 725 omitted for clarity.

726

727

728

729 


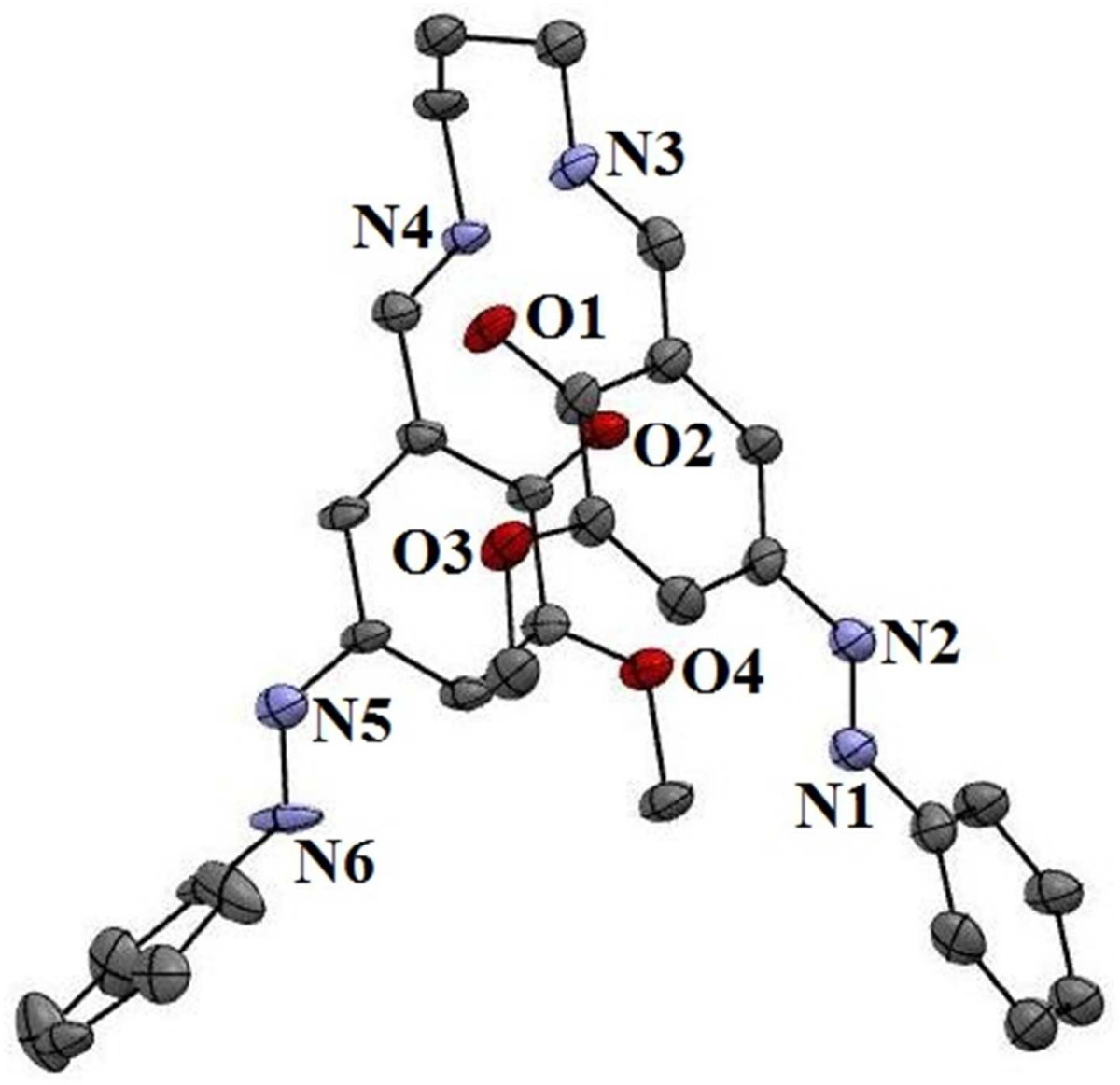

748 Fig. 2. Ortep view of the ligand $\left(\mathbf{H}_{2} \mathbf{L}\right)$. Atoms are shown as $30 \%$ thermal ellipsoids. $\mathrm{H}$ atoms are 749 omitted for clarity. 


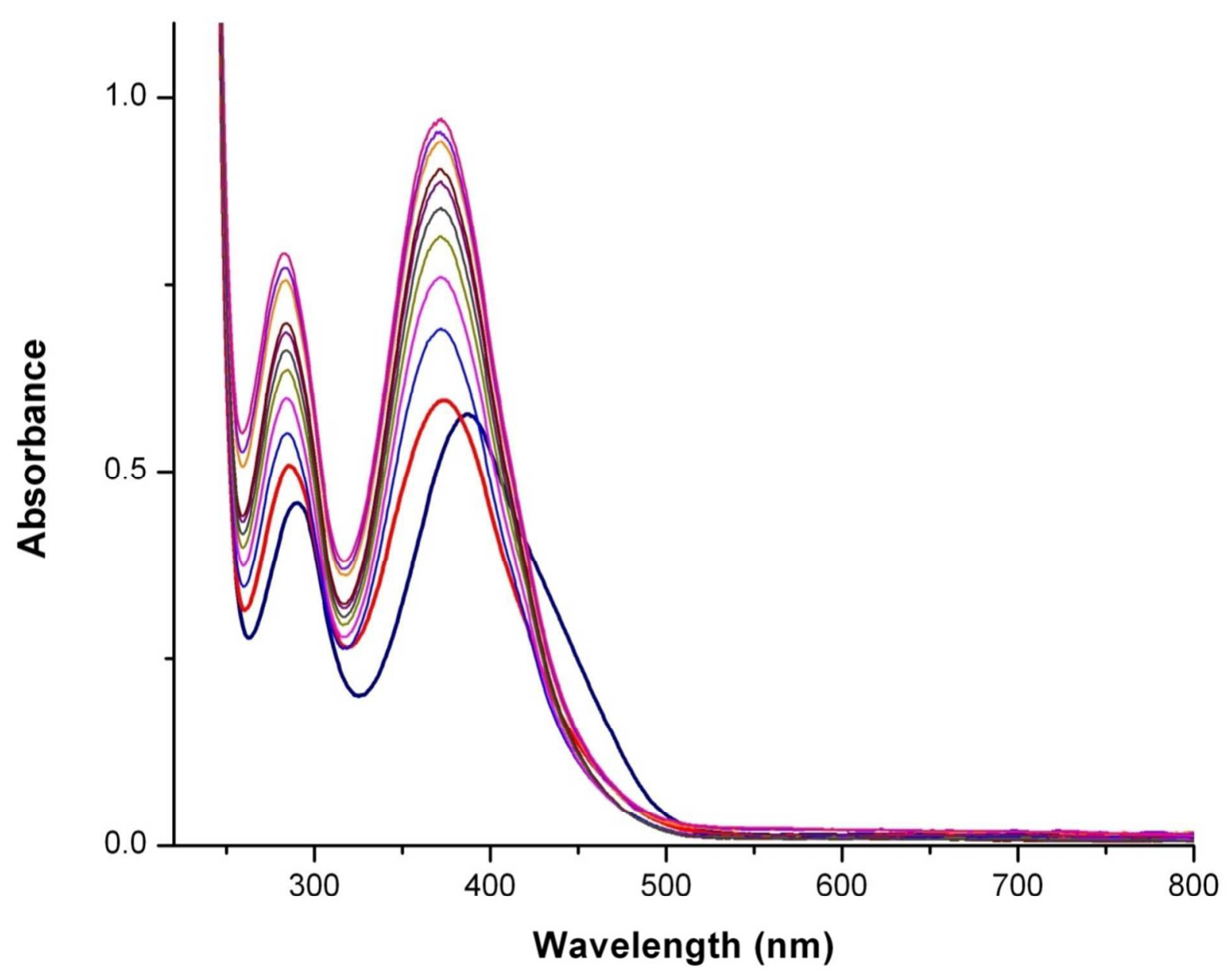

761 Fig. 3. Absorption titration of $\mathbf{H}_{2} \mathbf{L}(10 \mu \mathrm{M})$ with gradual addition of $\mathrm{Al}^{3+}, 0-10 \mu \mathrm{M}$ in $\mathrm{MeCN} /$

762 HEPES buffer at $p^{\mathrm{H}} 7.4$. 


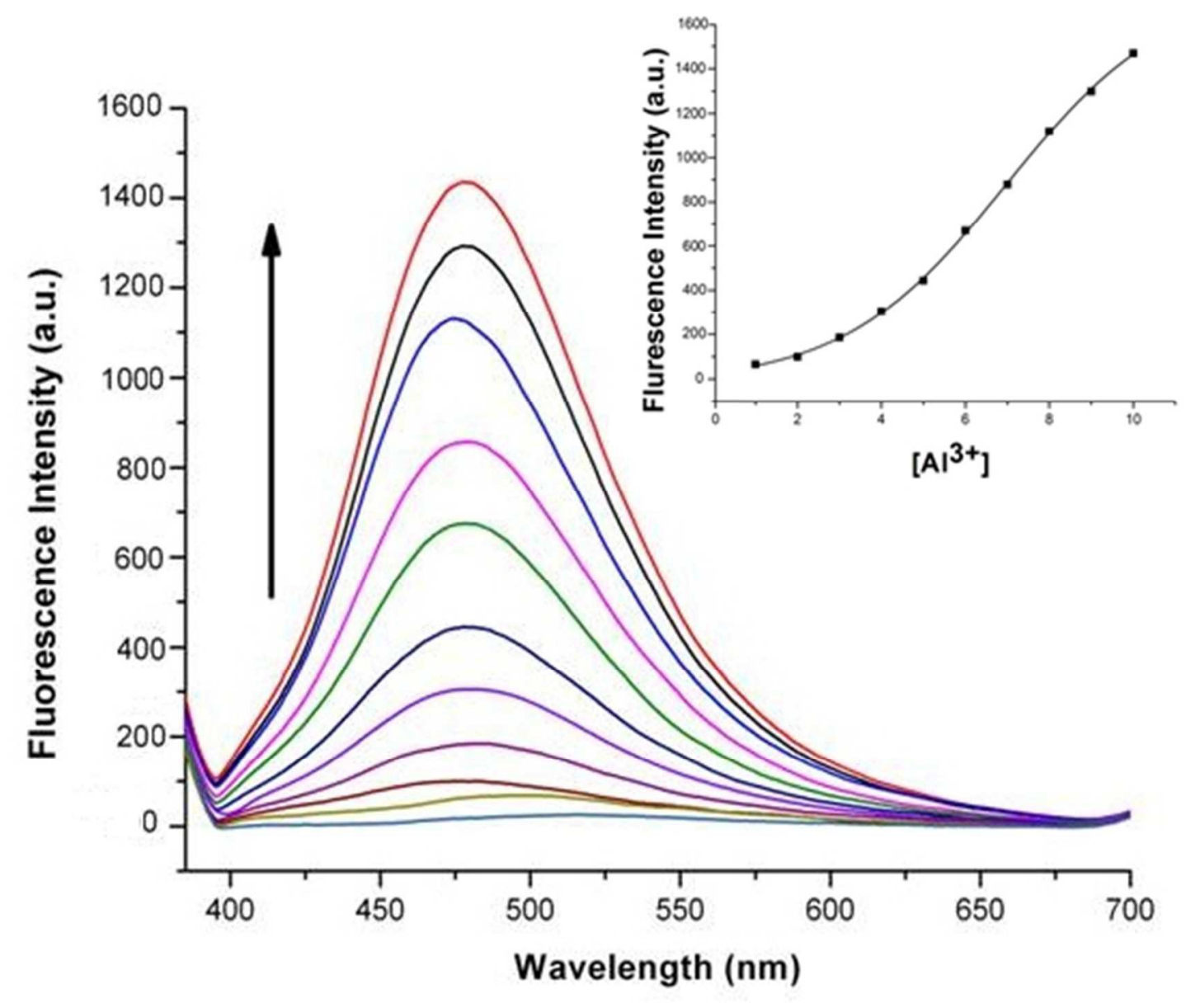

782

780

781

774

775

776

777

778

779

783

784 Fig. 4. Fluorescence titration of $\mathbf{H}_{2} \mathbf{L}(10 \mu \mathrm{M})$ in HEPES buffer at $\mathrm{pH}=7.4$ by gradual addition of

$785 \mathrm{Al}^{3+}(0-10 \mu \mathrm{M})$ with $\lambda \mathrm{em}=478 \mathrm{~nm}(5 / 5$ slit $)$. Inset: non-linear plot of fluorescence intensity vs.

786 concentration of $\mathrm{Al}^{3+}$ ion. 


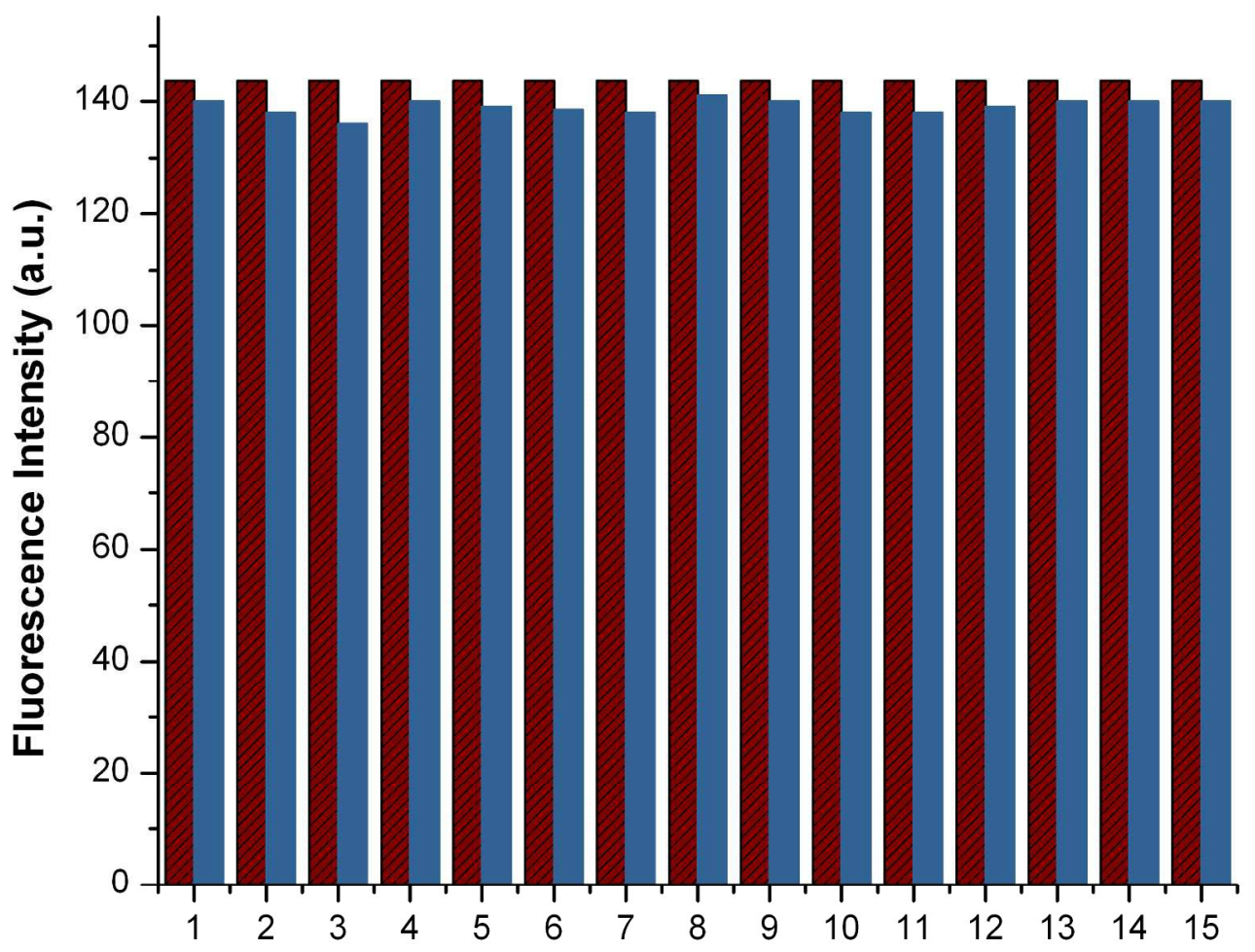

799

800

801

802 Fig. 5. Relative fluorescence intensity profile of $\left[\mathrm{H}_{2} \mathrm{~L}-\mathrm{Al}^{3+}\right]$ system in the presence of different

803 cations in HEPES buffer at $\mathrm{pH}$ 7.4. $\mathbf{H}_{2} \mathbf{L}(10 \mu \mathrm{M})+\mathrm{Al}^{3+}(10 \mu \mathrm{M})+\mathrm{M}^{\mathrm{n}+}(500 \mu \mathrm{M})$, where $\mathrm{M}^{\mathrm{n}+}=(1-$

$804 \mathrm{Cd}^{2+}, 2-\mathrm{Co}^{2+}, 3-\mathrm{Cr}^{3+}, 4-\mathrm{Cu}^{2+}, 5-\mathrm{Fe}^{3+}, 6-\mathrm{Hg}^{2+}, 7-\mathrm{K}^{+}, 8-\mathrm{Mn}^{2+}, 9-\mathrm{Na}^{+}, 10-\mathrm{Ni}^{2+}, 11-\mathrm{Sn}^{2+}, 12-\mathrm{Zn}^{2+}, 13-$

$\left.805 \mathrm{Ag}^{+}, 14-\mathrm{Fe}^{2+}, 15-\mathrm{Ca}^{2+}\right)$.

806

807

808 


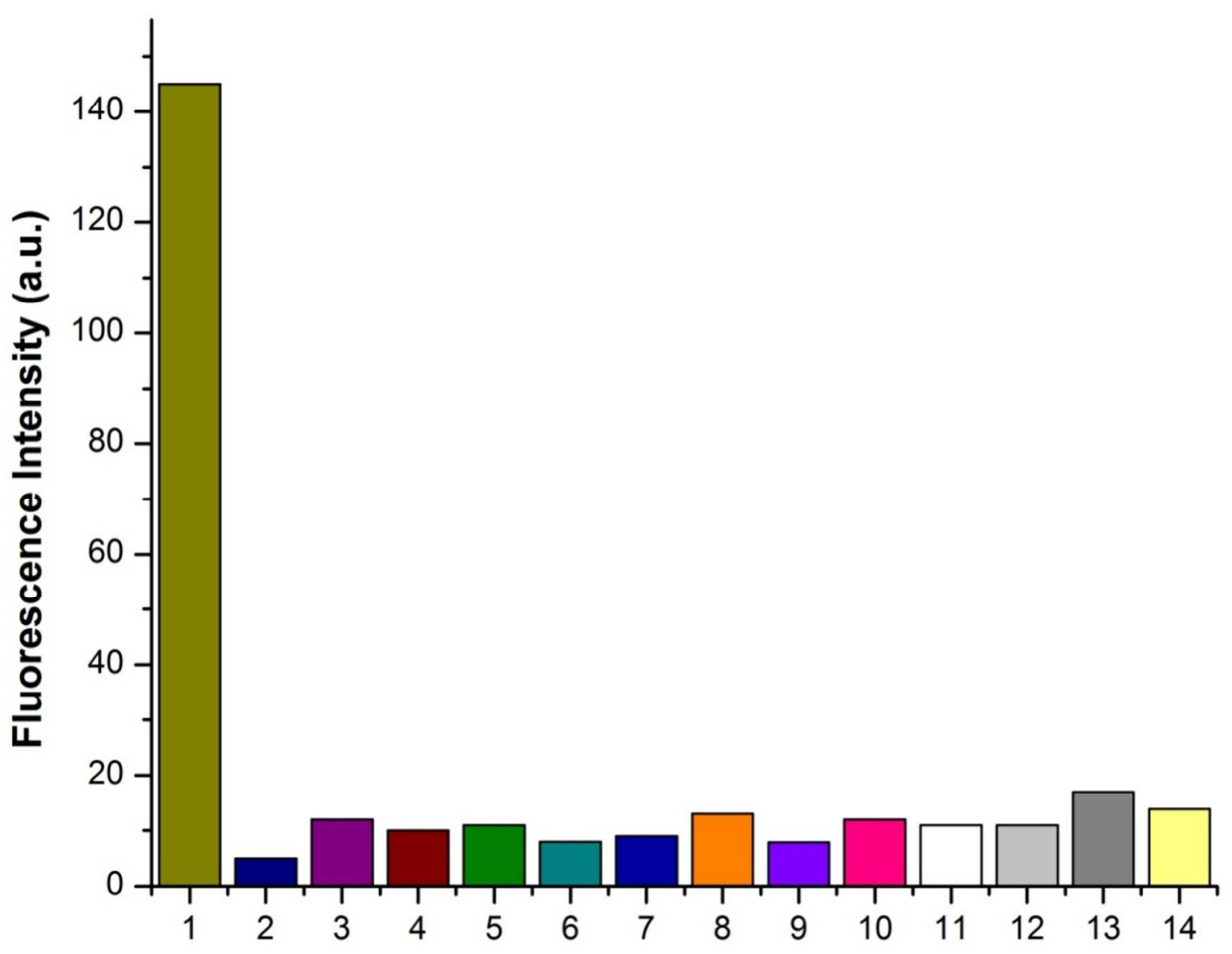

821

822 Fig. 6. Relative fluorescence intensity profile of $\mathbf{H}_{2} \mathbf{L}(10 \mu \mathrm{M})$ in the presence of various 823 common anions $(50 \mu \mathrm{M})$ in HEPES buffer at $\mathrm{pH} 7.4$.

$8241-\mathbf{H}_{2} \mathbf{L}+\mathrm{Al}^{3+}, 2-14 \mathbf{H}_{2} \mathbf{L}+$ Anions, Anions $=2-\mathrm{S}_{2} \mathrm{O}_{3}{ }^{2-}, 3-\mathrm{S}^{2-}, 4-\mathrm{SO}_{3}{ }^{2-}, 5-\mathrm{SO}_{4}{ }^{2-}, 6-\mathrm{SCN}^{-}, 7-\mathrm{N}_{3}{ }^{-}$, $8258-\mathrm{AsO}_{4}{ }^{3-}, 9-\mathrm{PO}_{4}{ }^{3-}, 10-\mathrm{ClO}_{4}{ }^{-}, 11-\mathrm{OAc}^{-}, 12-\mathrm{Cl}^{-}, 13-\mathrm{NO}_{2}{ }^{-}, 14-\mathrm{NO}_{3}{ }^{-}$

826

827 


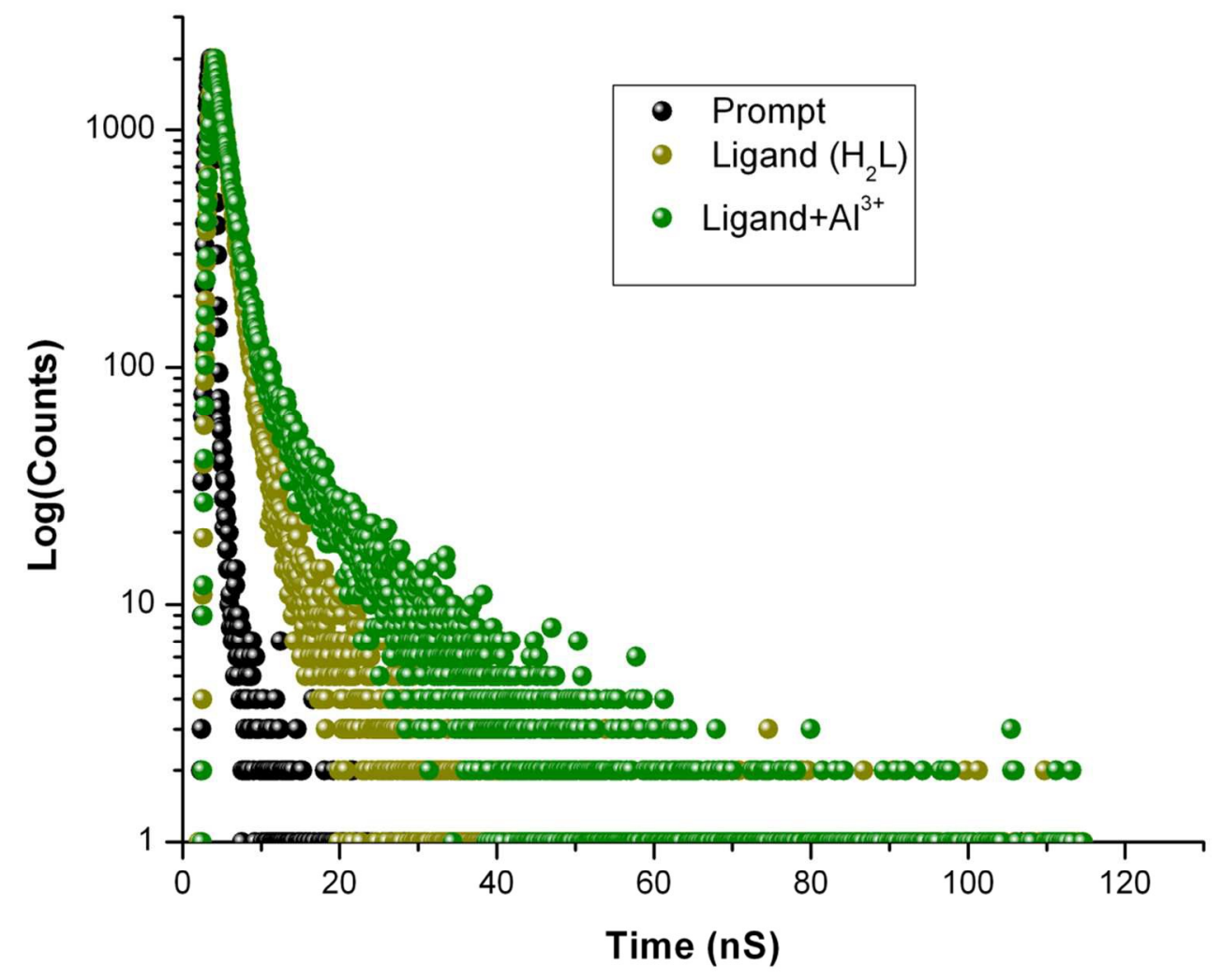

844 Fig. 7. Time-resolved fluorescence decay curves (logarithm of normalized intensity vs time in ns) of $\mathbf{H}_{2} \mathbf{L}$ in the absence $(\bigcirc)$ and presence $(\bigcirc)$ of $\mathrm{Al}^{3+}$ ion, $(\mathbf{O})$ indicates decay curve for the scattered $(\lambda \mathrm{ex}=478 \mathrm{~nm})$. 


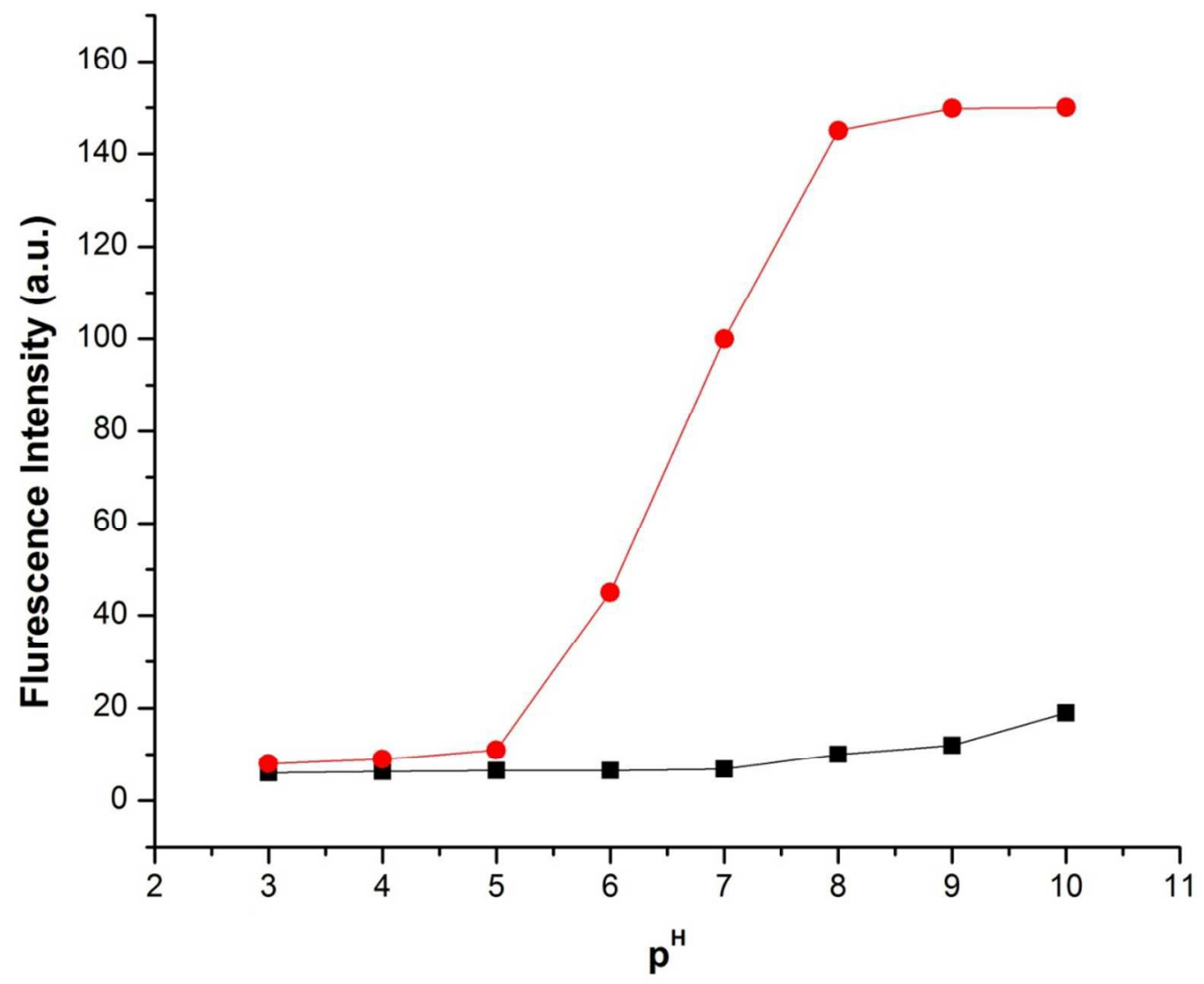

867 Fig. 8. Fluorescence intensity of $\mathbf{H}_{2} \mathbf{L}$ (black box; $10 \mu \mathrm{M}$ ) in the absence and presence of $\mathrm{Al}^{3+}{ }^{+}$ion

868 (red circle, $10 \mu \mathrm{M}$ ) ion at various $\mathrm{pH}$ values in HEPES buffer.

869

870

871

872

873

874 
876

877

878

879

880

881

882

883

884

885

886

887
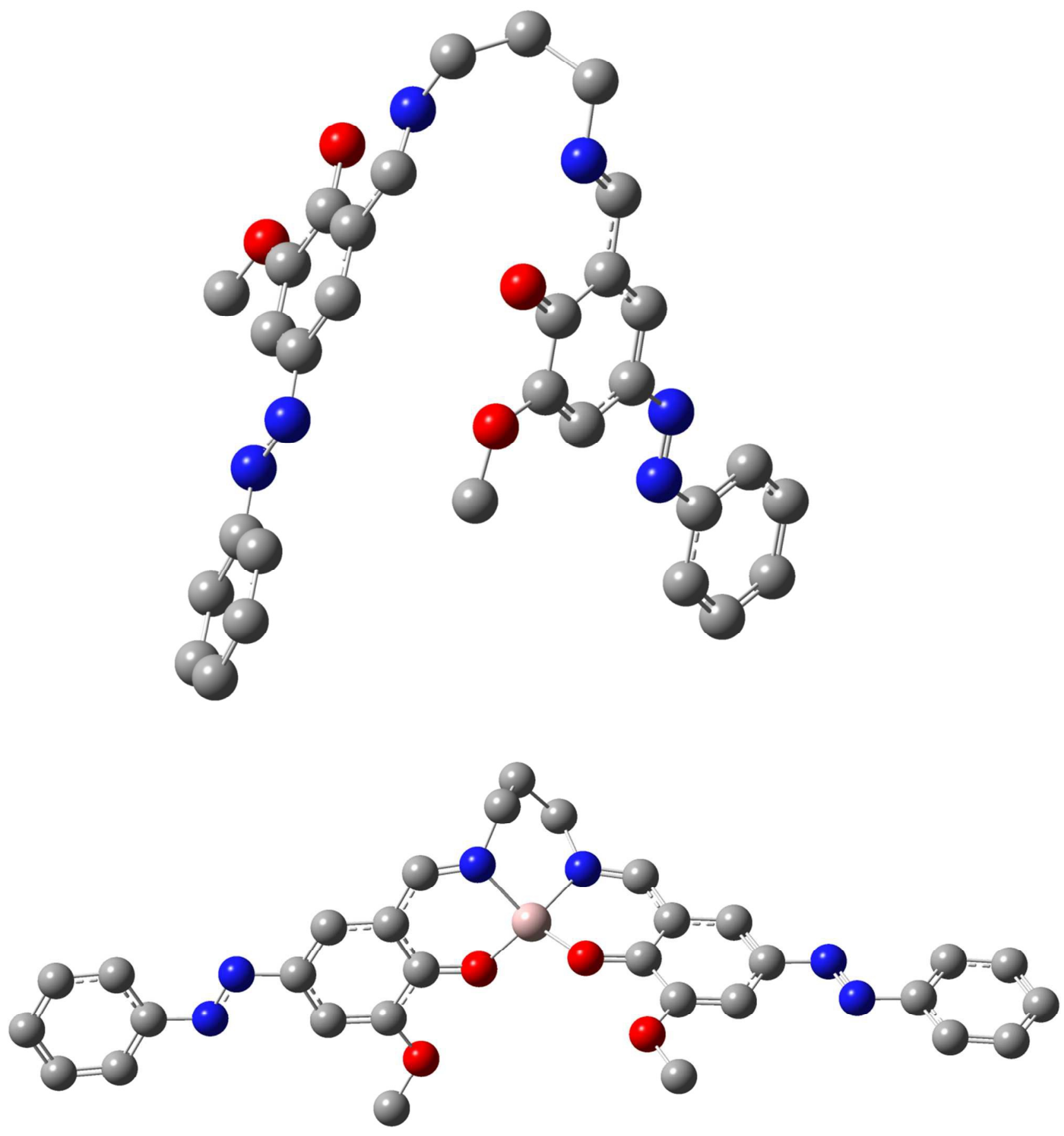

890 Fig.9. DFT optimized structures of $\mathbf{H}_{2} \mathbf{L}$ and $[\mathrm{Al}(\mathrm{L})]^{+}$. H-atoms are omitted for clarity. 
895

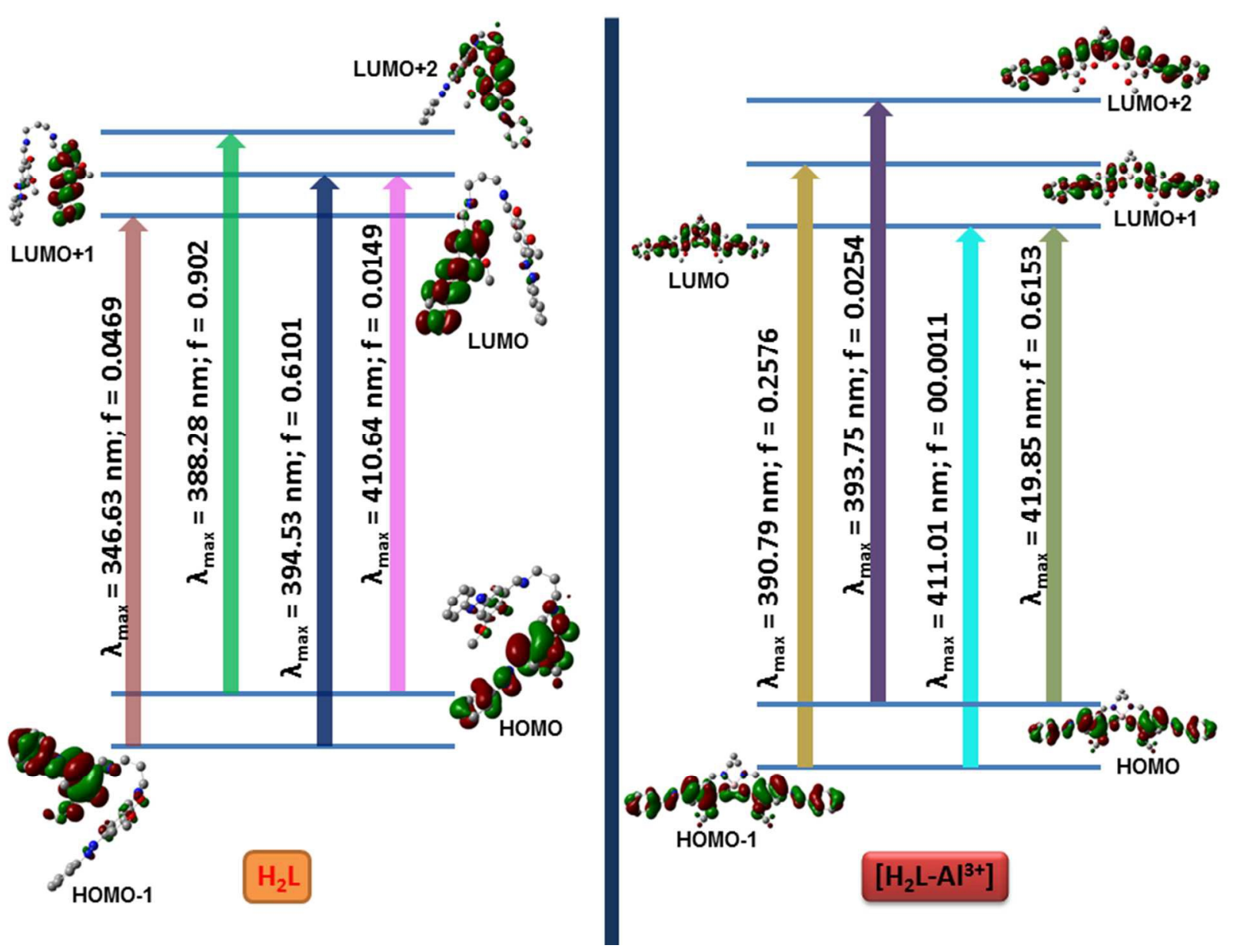

899 Fig.10. Pictorial representation of key transitions of $\mathbf{H}_{\mathbf{2}} \mathbf{L}$ and [Al(L)] $]^{+}$. 
903

904

905

906

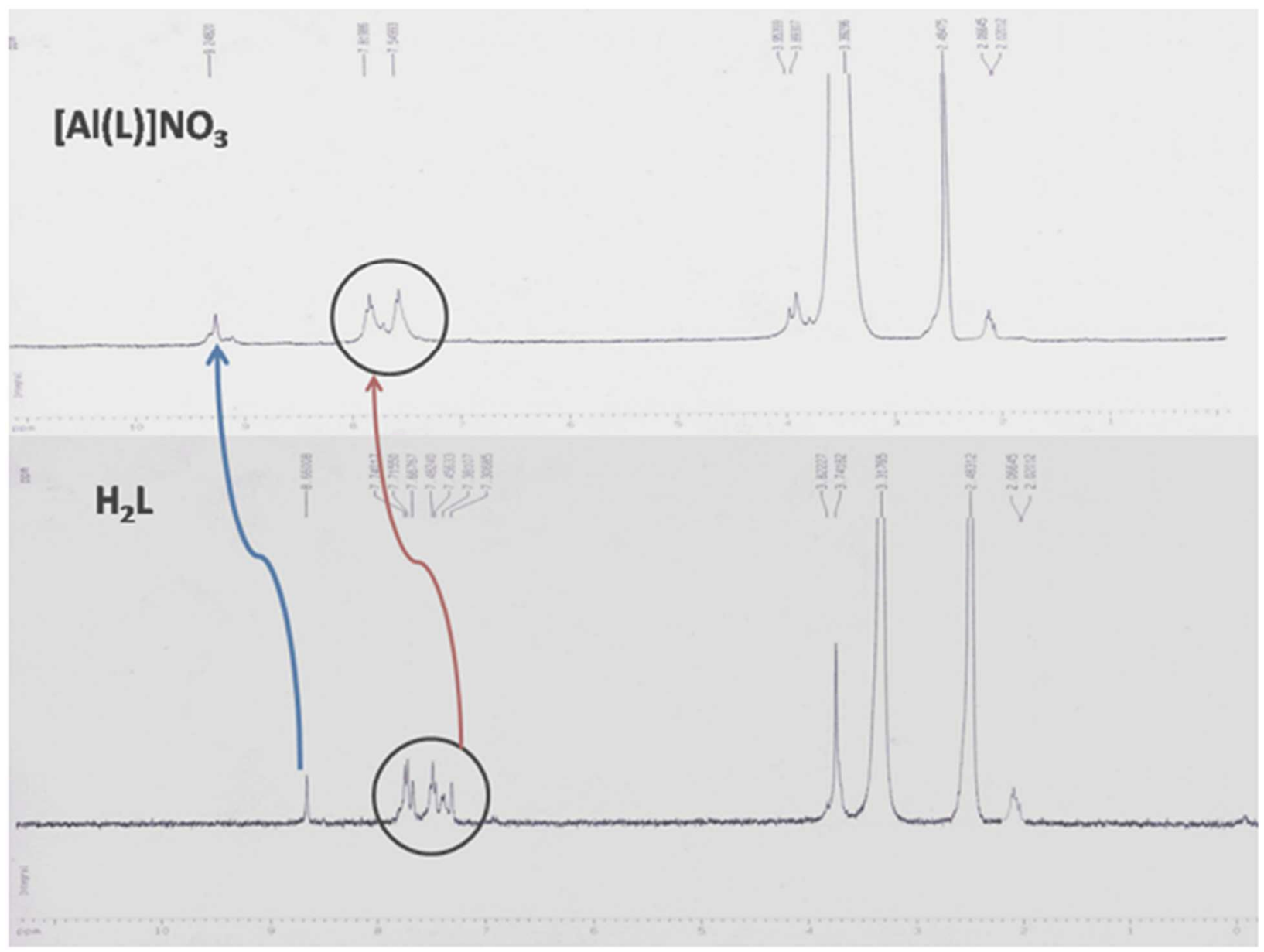

907

908

909 Fig. 11. NMR titration of $\mathbf{H}_{2} \mathbf{L}$ in presence of 1 eq. of $\mathrm{Al}^{3+}$ ion.

910 
912

913

914

915

916

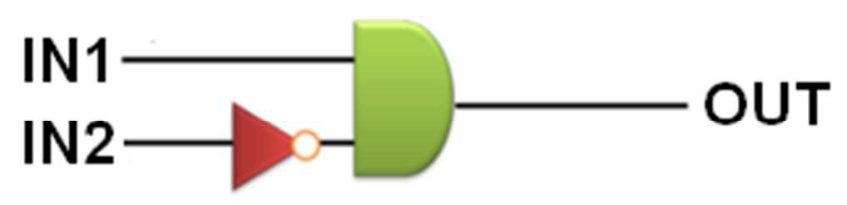

917 Fig. 12. Pictorial representation of Logic Gate.

918

919

920

921

922

923 


\title{
A Robust Fluorescent Chemo sensor for Aluminium Ion Detection Based on Schiff base Ligand with Azo Arm and Application in Molecular Logic Gate
}

\section{Saikat Banerjee ${ }^{a}$, Paula Brandão ${ }^{b}$ and Amrita Saha ${ }^{a, *}$}

\author{
Herewith, we have reported a new Schiff base chemosensor with azo arm for $\mathrm{Al}^{3+}$ ions. The \\ sensor has been well characterized using different techniques like single crystal x-ray, NMR, IR, \\ UV etc. It shows excellent selectivity over other cations and anions. Detection limit of the sensor \\ was found to be $6.93 \mathrm{nM}$.
}




\title{
Graphical Abstract (Pictogram)
}

\begin{abstract}
A Robust Fluorescent Chemo sensor for Aluminium Ion Detection Based on Schiff base Ligand with Azo Arm and Application in Molecular Logic Gate
\end{abstract}

Saikat Banerjee ${ }^{a}$, Paula Brandão $0^{b}$ and Amrita Saha ${ }^{*^{a}}$

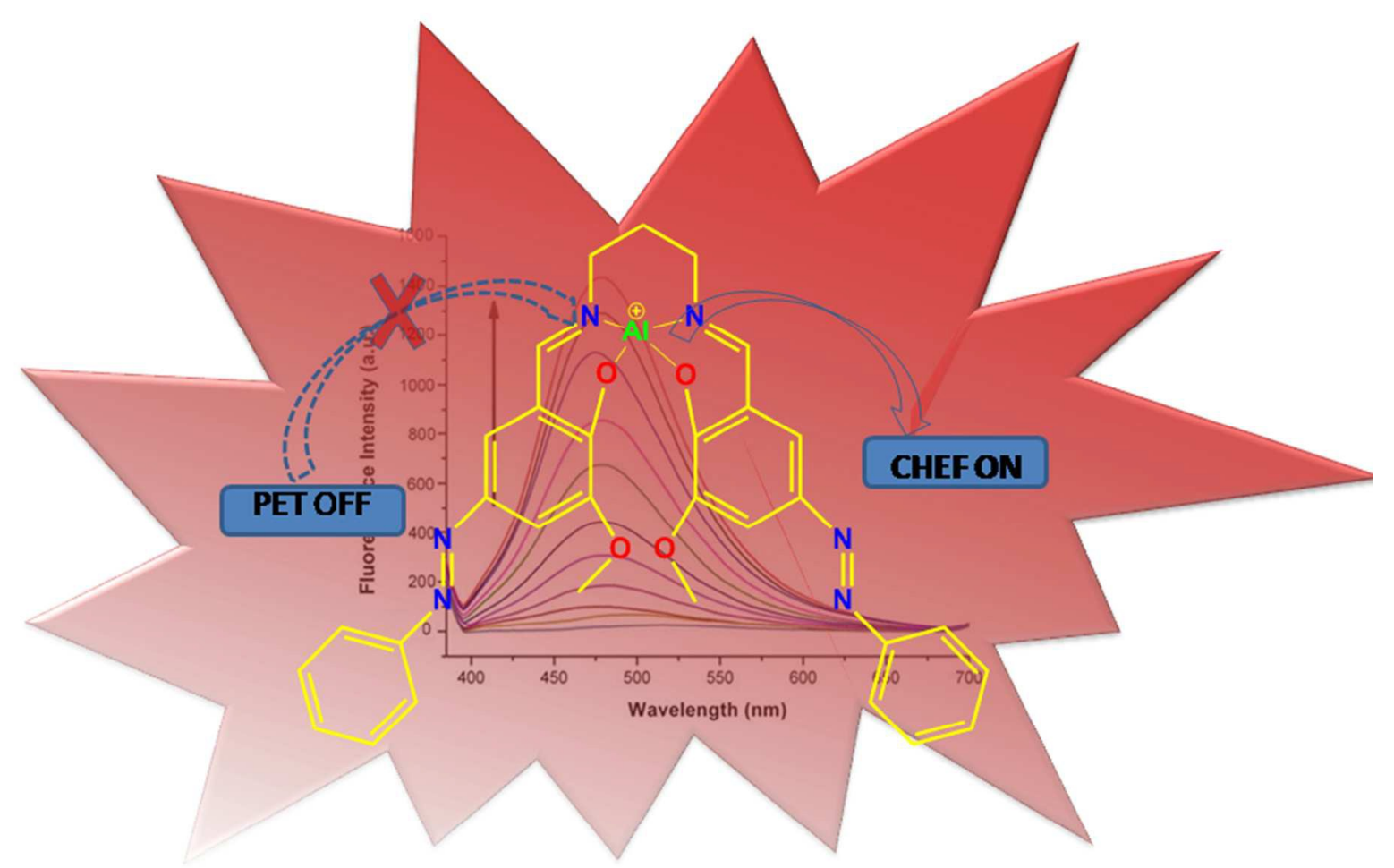

